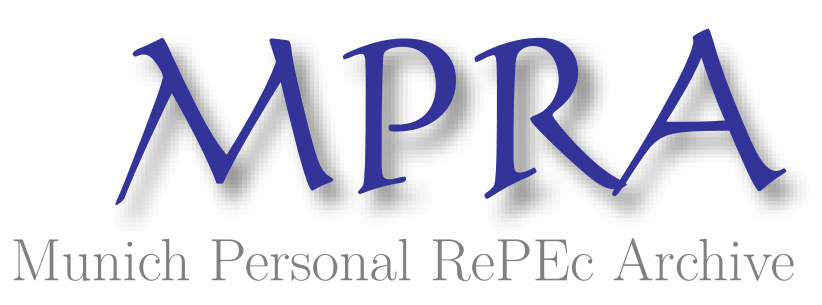

\title{
Islamic equity funds: an Italian perspective
}

Stefano, Collina

14 September 2009

Online at https://mpra.ub.uni-muenchen.de/22343/

MPRA Paper No. 22343, posted 29 Apr 2010 10:22 UTC 


\section{Islamic Equity Funds: an Italian perspective}

Author:

Stefano Collina
Supervisor:

Prof. Stefano Gatti

September 2009

Paper submitted as fulfilment of the requirements of the Bachelor in Economics \& Finance (CLEF) - Università

L. Bocconi 


\begin{abstract}
Fuelled by the skyrocketing commodities prices and the booming middle-classes in emerging economies, the Islamic equity funds industry has been in the recent years one of the fastest growing sector in the global finance panorama.

This paper discusses the peculiar characteristics of an Italian equity portfolio constructed following the Sharia'a provisions and the opportunities this industry offers to Italian financial institutions in both the retail and wholesale markets.

This paper also discusses how these funds weathered the financial crisis and how they are able to offer a value-added to particular investor classes along with the ethical part.
\end{abstract}


to G. Cupini and M. Pinotti 


\section{Contents}

1 Introduction 5

2 Islamic Finance Principles $\quad 7$

2.1 Riba . . . . . . . . . . . . . . . . 7

2.2 Maisir . . . . . . . . . . . . . . . . 8

2.3 Gharar . . . . . . . . . . . . . . . . . . . . . . . 8

2.4 Haram Businesses . . . . . . . . . . . . . . . . . . . . 8

3 Stock Selection $\quad 9$

3.1 Haram Businesses . . . . . . . . . . . . . . . . . . . . . . 9

3.2 Other Not Sharia'a Compliant Businesses . . . . . . . . . . . . 9

3.3 Financial Ratos . . . . . . . . . . . . . . . . . . . . 10

3.4 Other Provisions . . . . . . . . . . . . . . . . . . . 11

3.5 Provisions Implications . . . . . . . . . . . . . . . . . . 11

4 Funds Management $\quad 13$

4.1 Management. . . . . . . . . . . . . . . . . 13

4.2 Zakah (Purification) . . . . . . . . . . . . . 13

4.3 Sharia'a Board . . . . . . . . . . . . . . . . . 14

4.4 Costs Problem and Recent Trends . . . . . . . . . . . . . . . . 14

$5 \quad$ Islamic Italian Equity Portfolio $\quad 16$

5.1 Methodology . . . . . . . . . . . . . . . . . . 16

5.2 Stock Selection . . . . . . . . . . . . . . . . 18

5.3 Absolute Performance . . . . . . . . . . . . . . . . . 20

5.4 Absolute and Relative Risk . . . . . . . . . . . . . . . 21

5.5 Risk-Adjusted Performance . . . . . . . . . . . . . . . . 23

5.6 Remarks . . . . . . . . . . . . . . . . 25

$\begin{array}{llr}6 & \text { Conclusions } & 27\end{array}$

$\begin{array}{ll}\text { A Funds Comparison } & 31\end{array}$

A.1 Methodology ... . . . . . . . . . . . . . . 31

A.2 Global Equity Mutual Funds . . . . . . . . . . . . . . . 33

A.2.1 Remarks . . . . . . . . . . . . . 39

A.3 Global Equity ETFs . . . . . . . . . . . . . . . . . . . . . . . . . . . 41

A.3.1 Remarks . . . . . . . . . . . . . 45

A.4 Sharpe Ratio in Funds Comparison . . . . . . . . . . . . . 47

A.4.1 Remarks . . . . . . . . . . . . . 48 


\section{References}




\section{Introduction}

During the past years, partially thanks to the rise of the oil price and the strong growth of many emerging economies, one of the rising stars in the world of finance has been Islamic finance. From the skyscrapers of Dubai and Kuala Lampur, to the XIX century palaces of Paris, there has been a growing interest in this business.

In this framework a particular sector showed an impressive growth: the Islamic equity funds industry.

Fuelled by the appetite of the HNWIs in the Gulf and of the booming middleclass of Islamic countries as Malaysia and Indonesia, the AUM rose three times to US\$ 20 billion in 2008 (Failaka Advisors). However, as the entire Investment Management industry, the Islamic equity funds industry has been seriously hit by the financial crisis, a crisis that did not spare the GCC and South-East Asia. The most relevant consequence has been a large outflow from equity investments particularly among the mass-affluent (portfolio weight of equities from $80 \%$ to $40 \%$ ) and HNWIs (from $60 \%$ to $20 \%$ ) (2009, E\&Y IFIR).

It is important to underline that this outflow is probably only temporary: the recipient of the outflow has been the money market (usually considered a safe harbour during bad weather) and, as the movements in early 2009 demonstrated, these investors are slowly returning to equities.

Although the heavy toll, the crisis has also brought benefits to a fossilizing industry.

The crisis has pushed ahead the transformation from an Islamic-countriesfocused investing strategy to a more broad country breakdown panorama: in 2004 the weight of MEA+Asia was 51\%, in 2008 only $25 \%$ (2009, E\&Y IFIR).

Besides, the crisis pushed the Islamic equity funds player to seek new market opportunities, particularly in countries like Turkey, Iran and Pakistan that have been barely interested by the Islamic finance boom (2009, E\&Y IFIR): in fact the heavy concentration on few oil and export dependent economies (GCC, Malaysia, etc..) is one of the causes of the sharp industry growth slowdown.

Last but not least, the crisis taught the industry that the excessive concentrations on HNWIs and on mass-affluent is dangerous: although, particularly the latter, have an high propensity to invest in Islamic products, they are very susceptible to market conditions and quickly shift from a low-performing asset to the safer money-market (2009, E\&Y IFIR). As the shift from a uberclass-centric industry to a mass-affluent-focused one has been one of the major reasons behind the impressive growth, the entrance in the institutional 
market has become a must for the stability and development of the industry. SWFs, endowments and particularly pension funds are becoming more and more widespread and interested in compliant products: all investors that usually guarantee stabler money flows. Especially pension funds (strongly correlated with the rise of the emerging economies and the growth of the middle-class) should be the major target of the Islamic equity fund industry: it is actually the only type of investor that increased the weight of equities in its portfolio (2009, E\&Y IFIR).

The crisis clearly offered to the Islamic funds industry an opportunity to grow, but it also offered a test bed to actually test the profit potential. In the past many tried to understand the behaviour of this kind of funds, usually obtaining heterogeneous results. However they identified a series of common elements: lower risk, higher costs and a widespread diversification problem. This paper would like to be a brief insight into this not largely explored territory, an insight written using two particularly eyes: the eye of a (post)-crisis analysts and the eye of an Italian one.

This paper would like to understand how these funds weathered one of the worst financial crisis of the last sixty years, to understand if they are able to offer a value-added to investors along with the ethical part.

This paper would like to analyse what opportunities this industry offers to the Italian financial institutions and to the Italian equity market, to understand how can Italian institutions leverage their position and if the Italian market is compatible with this industry.

In the first three chapters it has been focussed on the characteristics underlying the Islamic equity funds industry: what are the Islamic guidelines and how they are applied to the stock selection process and fund management. Based on these provisions, it has been constructed a portfolio of Italian equities based on the MIBTEL. While in the appendix, it has been conducted a brief comparison between Islamic and traditional funds and ETFs focussing on the period interested by the financial crisis.

The facts and non-facts, the problems and the doubts that interest this industry are much more numerous than these and, as the reader will find out, there are a lot of question that will be left unanswered.

This paper would not be a summa theologiae of the Islamic equity funds world (this would require some volumes), but the answer to the most pressing questions in the Bel Paese 


\section{Islamic Finance Principles}

Before entering in the details regarding the function of Islamic equity funds, it is extremely important to understand what are the religious and Islamic law principles that lie behind the whole Islamic finance concept.

While there are several texts written by eminent Islamic scholars about this subject, the Qur'an and the Sunna are still the source of the majority of the guidelines governing the management of an Islamic equity fund and, in general, of Islamic finance.

The Qur'an and the Sunna are primarily holy books, but, thanks to their "realism", they are also a guide for many believers about how to behave in the social and economical life. Besides, the Sharia'a itself sets a series of principles about trade and investment.

The four pillars are: the prohibition of Riba, the prohibition of Gharar, the prohibition of Maisir and the prohibition to be involved in haram businesses.

\section{$2.1 \quad$ Riba}

The western banking system is practically based on interests: in exchange for the money you deposit or you borrow, you will receive or you will have to pay a particular sum that can be considered a remuneration of your commitment or a burden of the service offered to you.

The idea that interests are morally not acceptable is rooted in many religions, in the past also Christians used to condemn this as a form of "usury" (the financing job has been originally run by Jews).

The underlying theory is that money generated from other money is actually unproductive and, besides, it generates social and economical inequalities. People who have money should help people who need it, not exploit them charging a greater burden.

While the western world has (nearly) totally abandoned this idea, the so called riba is still an important pillar of Islam and in countries where the law is based on the Sharia'a it is a fundamental element of commercial law.

In the Qur'an we can read that "Those who charge riba are in the same position as those controlled by the devil's influence. This is because they claim that riba is the same as commerce. However, God permits commerce, and prohibits riba. Thus, whoever heeds this commandment from his Lord, and refrains from riba, he may keep his past earnings, and his judgement rests with God. As for those who persist in riba, they incur Hell, wherein they abide forever "(Qur'an 2:275), statement that is considered the foundation of this prohibition.

We should underline that Riba are interests (or other premiums) that don't 
correspond to a real increase in value, so capital gains are completely lawful.

\section{$2.2 \quad$ Maisir}

em "In both of them there is great harm although there is some advantage as well in them for men, but their harm is much greater than their advantages " (Qur'an 2:219). These are the words used in Qur'an to describe gambling and related businesses, activities that are strictly prohibited. The rationale is that gambling involve an high level of risk and the possibility to seriously harm individuals.

The first implication is that instruments that involve an extraordinary level of risk are illicit, in this case we are talking mainly about exotic OTC derivatives.

But the main implication is that the traditional insurance business model is illicit, too: it can be considered as a form of gambling (actually the insurance company is a player that developed a mathematical system to win) that, besides, involves an high level of uncertainty (see below).

\subsection{Gharar}

The meaning of "Gharar" is literally "uncertainty". Every product containing gharar is actually considered illicit. The rationale is that in a contract characterized by gharar (as a derivative), one side can exploit its superior knowledge (informative asymmetry) to speculate and so creating the possibility of an unfair damage to the counterpart.

It is important to understand how this principle has evolved during the last decades: in fact, if strictly applied, it will forbid an array of contracts/product now widely diffused in the business world. Hence, jurists developed the idea of "excessive gharar": contracts that involve a limited quantity of gharar and that are essential for the industrial, agricultural and commercial development should be allowed, while contracts that involve pure speculation, "wherein the object of sale does not exist at contract inception" (El-Gamal, 2006) are totally illegal.

\subsection{Haram Businesses}

Haram is the word used to indicate illicit goods and services: alcohol, pork, gambling, pornography and weapons are examples of what is considered haram. The believer should not be involved with these kinds of goods/businesses: neither as a consumer, nor as an entrepreneur/investor. 


\section{Stock Selection}

The sharia'a principles mentioned in the last chapter directly affect the construction of Islamic equity portfolios imposing a series of constrictions and provisions that heavily affect the manager investment decisions.

The stock selection process is probably the most important step in the construction of an Islamic equity fund.

Some sharia'a principles are easily transferable to the AM business, but others require not so immediate conjectures. While the general theories are pretty much the same, it is the application in the real world that, particularly in the past, has been characterized by an heavily fragmented framework dominated by subjective consideration.

A step toward the harmonization of the stock selection guidelines has been recently made with the institution of a series of common standards by AAIOFI: the FAS. The FAS are actually accounting standards, but they also try to fill the critical loophole that has dominated and is still dominating one the most discussed part of the stock picking process: the acceptable financial ratios.

\subsection{Haram Businesses}

The guideline regarding "illicit" businesses is the most simple and immediate transfer from the holy books to the AM practice. Simply, Islamic equity funds can not invest in companies operating in haram businesses like alcohol, pork, gambling, pornography and weapons.

While some scholars/jurists state that companies should not be involved in haram businesses at all, the mainstream opinion is that a limited involvement is acceptable ( $5 \%$ of the revenues or profits).

\subsection{Other Not Sharia'a Compliant Businesses}

Some companies are inadmissible not because they operate in haram businesses, but because the way they are run involve riba, maisir or gharar. An example are "traditional" banks that generate the large part of their revenues from interests (hence riba) and "traditional" insurance companies that base their activities on maisir and gharar. Obviously Islamic banks and Islamic insurance companies are completely legitimate investments.

Besides, simply having to do with product characterized by riba, masir or gharar is not illicit. So a broker involved in options is not violating any sharia'a principle, in fact it generates its revenues from commissions not from riba. Instead, a prop house trading options is generating profits from gharar products, hence violating Islamic guidelines. 


\subsection{Financial Ratos}

Financial ratios requirement is probably the most controversial, although extremely important, part of the stock selection process. We are not talking about the standard ratios used in financial statement analysis, but indicators that has been developed precisely for the Islamic equity industry. To be sharia'a compliant, companies should not be heavily indebted nor they should heavily rely on revenues generated by credits. An indebted company is actually "victim" of riba and it is susceptible to receive pressures from institutes, like traditional banks and NBFCs, that run illicitly their businesses. Islamic finance professionals and scholars have produced a wide array of different way to detect inadmissible companies, however the mostly used (and the one recognized in FAS 21) method is based on three pillars: the "debt/average capitalization ratio", the "AR/average capitalization" ratio and the "cash+ib securities/average capitalization ratio".

$$
D / C=\frac{\text { total debt }}{12 \text { months average market capitalization }}
$$

The $\mathrm{D} / \mathrm{C}$ ratio measures how much a company is indebted compared to its market value (and not book values as in a standard D/E ratio). It is usually more correct to consider only interest-bearing debt as numerator, but it is pretty common to use the total debt to make speedier and simpler the process. An admissible company has a D/C ratio below $33.33 \%$

$$
\begin{gathered}
A R / C=\frac{\text { account receivables }}{12 \text { months average market capitalization }} \\
C a+S / C=\frac{\text { cash }+ \text { interest bearing securities }}{12 \text { months average market capitalization }}
\end{gathered}
$$

The AR/C ratio measures how much a company is offering delayed payments (and credit) to its clients compared to its market dimension, while the $\mathrm{Ca}+\mathrm{S} / \mathrm{C}$ ratio measures how much a company is investing its liquidity in illicit products compared to the same value. Both ratios want to detect companies that heavily rely on products or business strategies that involve 
riba. While these ratios are less problematic than the one described before, there are companies operating in particular industries (as retail) that can be dismissed due to their heavy credit and cash positions.

The limit is equally set for both ratios at $33.33 \%$.

These are the three mostly used indicators, but as we said the world is much more variegated. Someone prefer using the D/A (Debt/Assets) ratio instead of the D/C ratio commonly used, others prefer to substitute the two other indicators with the ratio between Non-Operating Income and Operating Income (Babikir, 2001) or the ratio between interest-income and total income (both should not be more than 5-10\%).

\subsection{Other Provisions}

Especially in the past, some funds (and some Islamic scholars) have implemented other screening systems.

Here we should recall the liquidity provision (Usmani, 2007): it argues that a company can be included only if it holds some liquid assets. If a relevant part of the company assets is in liquid form, it is actually trading money that cannot be exchanged except at par. So, this provision requires admissible companies to held liquid assets valued no more than the $33.33 \%$ (or sometime more) of the market capitalization.

$$
L / C=\frac{\text { liquidassets }}{12 \text { months average market capitalization }}
$$

However, it is important to underline that this provision is actually rarely used and it is not recognized in any FAS.

Other provisions used by Islamic equity funds refer mainly to sector, country and other weightings. Some GCC and Malaysian funds have limited the weight of foreign stocks, while others have imposed minimum cash quantities or restriction to blue-chips or companies listed on major stock exchanges.

\subsection{Provisions Implications}

The rationale behind stock picking guidelines is clearly religious or, generally speaking, ethical. However it is possible to infer that, de facto, some of these 
idea are to some extent also used in traditional stock selection process.

The $\mathrm{D} / \mathrm{C}$ ratio requirement actually eliminates over-indebted companies. While the indebtedness depends on many factors (tax system, industry, maturity, etc..), without doubts it is a sign of risk: an indebted company is characterized by a financial status that can turn being dangerous in weak markets or after different kinds of shocks. Obviously this selection can also hamper active AMs, i.e. it will be usually difficult to invest in start-ups or problematic companies considered undervalued.

As we aforementioned, the $\mathrm{AR} / \mathrm{C}$ and $\mathrm{Ca}+\mathrm{S} / \mathrm{C}$ ratios can generate few problems with companies operating in particular industries. However these guidelines also result in selecting companies that are less dependent on macroeconomic variables: a company relying on account receivable could be encounter serious problems in a deteriorating economy where clients become more insolvent, on the other side a company investing a part of its assets in fixed-income securities could be harmed by rising interest rates. In few words, as we concluded talking about the $\mathrm{D} / \mathrm{C}$ ratio, these provisions isolates less risky companies with a lower beta (Kraeussl and Hayat, 2008).

But another important implications of sharia'a requirements is the limited diversification. The haram, riba and gharar provisions actually make inadmissible important economical sectors (particularly financial services, insurance and a chunk of the defence\&aerospace industry) and financial ratios seriously affects decisions regarding other ones. The diversification problem has been repeatedly underlined by professionals and researches (Abderrezak, 2008 and Babikir, 2001) and it is still one of the major downsides of Islamic equity funds. This is also one of the elements that explain the strong focus on global equities and quantitatively big stock markets (as USA) where you can more easily diversify. 


\section{Funds Management}

The stock picking is without any doubt the AM activity most affected by sharia'a provisions, however also the management of the funds is subject to a series of constrictions and special operations that make the Islamic equity fund management strongly different from a traditional one.

\subsection{Management}

The are two main ways to manage Islamic equity funds: the mudarabah and the agency (Usmani, 2007). In the first case the subscriber (rabb-ul-maal) provides capital to the AM (mudarib), forming a particular form of partnership called mudarabah. The AM is a partner and it will receive a share of the profit accrued to the fund (performance fee): if there is no profit, the AM will not receive anything.

In the second case the AM acts as an agent of the subscriber. It receives a predefined commission at the subscription and/or at regular deadlines (monthly, annually, etc..). The forbidden of the gharar implies that the commission should be not uncertain, hence fees based on the net value of the fund should not be allowed (the value change every day, so it is impossible to predetermine the commission). However many, mainly western, AMS systemically use this kind of fee structure and, generally, scholars have recently been more lax on this issue.

\subsection{Zakah (Purification)}

One important step in the management of an Islamic equity fund is the s.c. Zakah. The purification is the elimination of the profit attributable to the companies income generated from interests (riba) and the distribution of these to charities. If the company generated $4 \%$ of its profit from interests, $4 \%$ of the dividends should be given away.

The major discussion is regarding capital gains, some scholars argue that they should be purified, while others disagree (Usmani, 2007). The former states that the the market price can reflect these illicit profits and, besides, in open-ended funds it is possible that the subscribers redeem their quotas before the distribution of dividends (so the price still reflect these not purified dividends). The latter argues that it is impossible to determine what part of the price reflect profits generated from interests and, however, this part is surely infinitesimal in companies that have passed the financial ratios screenings. 


\subsection{Sharia'a Board}

One of the most peculiar characteristic of Islamic equity funds management structure is the existence of a body aimed at monitoring the activities of the fund and, generally, the (Islamic) ethical conduct of managers: the sharia'a board.

Although not every fund actually posses a sharia'a board (De Lorenzo, 2007), it is a distinguished element of any AM that want to offer some form of compliance guarantee.

The sharia'a board is composed of 1 to 4 scholars or, when not possible, sharia'a advisors specialized in Islamic financial and commercial law: obviously the dimension and the importance depend on the size and on the fund strategy (passive funds require minor controls). As a management composed of famed analysts, fund managers, etc.. is somewhat a guarantee of an high quality investment service, a sharia'a board composed of internationally recognized and influential scholars is a guarantee of an high quality supervision. The main role of the sharia'a board is to supervise the correct application of Islamic principles during the stock selection process, a role that it is not only passive, but usually involves the continuous screening of companies and of the market in collaboration with fund managers and auditors.

Besides, the board also:

- Supervises the portfolio purification and the allocation of illicit profits to reliable and legitimate charities and NGOs.

- Monitors the management, role similar to the one of the board of directors in traditional funds. It sets the objectives and orientations, makes sure fund managers act ethically and responsibly, evaluates the fund performance and the investment strategies.

- Ensures the fund transparency and the existence of a sufficient amount of information (fees, performance, purification, sharia'a compliance, etc..) for customers. It takes also care of the relations with regulatory and rating agencies.

\subsection{Costs Problem and Recent Trends}

The main problem faced by Islamic equity funds is without any doubt the costs, both for the asset manager and the customer.

Although, as we aforementioned, Islamic equity funds bear a series of peculiar problems, expenses are still one of the most discussed part of this business: 
both from customers and from asset managers. The extra costs, compared to a traditional fund, come from the cost of maintaining a complex structure that include additional bodies (primarily the sharia'a board), tortuous screening processes and the need of quite rare expertises.

Additionally, the (hypothetical) impossibility to apply a net value-based management fee (that it is extremely important in traditional mutual funds) resulted, mainly in the past, in fee structures characterized by abnormally high subscription and/or entrance fees (Babikir, 2001).

An Islamic equity fund, on average, costs 40 bps more than a traditional fund (Abderrezak, 2008) and, additionally, often requires much higher minimum investments (Babikir, 2001 and Abdzerrezak, 2008).

The strong growth and a general acceptance of laxer constrictions (particularly among western players) have surely lowered the average costs, but no economies of scale can completely erase costs that are essentials.

A particular way to reduce costs has been chosen by some of the most recent entrants: ETFs. ETFs are already a cheaper way to invest in indexes and generally in funds with a passive strategy, but clearly their benefits can be leveraged in Islamic equity funds.

Particularly Deutsche Bank (x-tracker), together with Barclays (iShares, now owned by Blackrock) one the two most active player in this field, has chosen to create a series of products called "Sharia ETF" structured around proprietary indexes based on major world indexes (S\&P 500, FTSE Europe 350, etc..): this allow the German bank to offer an unique, sharia'a compliant and cheaper way to access the world of Islamic equity investments. 


\section{$5 \quad$ Islamic Italian Equity Portfolio}

Although it had been expanding at a extremely brisk pace, the Islamic equity funds industry has traditionally focused its interest in a limited array of countries: USA, Islamic original countries and marginally the European equity market. In this section, it will be constructed an Islamic equity portfolio composed of companies listed at Borsa Italiana and, consequently, it will be conducted a comparative performance analysis with the market (MIBTEL).

\subsection{Methodology}

The considered portfolio has been hypothetically constructed in August/September 2008, hence using 1H 2008 book values and July 1st 2007 - June 30th 2008 average market capitalization values. This choice answers to the need to reduce the biases, particularly referring to the market capitalization: considering 2008 data would have affected the screening due to the extremely values touched during the sboom, oppositely considering 2007 data would have involved the use of high capitalization values reached during the peak. Generally, have been avoided companies listed on Borsa Italiana but with headquarters located abroad (i.e. Cell Therapeutics).

The Islamic provisions utilized are the standard ones: no haram, no other non-compliant businesses and the three FAS approved financial ratios. Regarding the latter, the limit value is set at $33.33 \%$ (or $1 / 3$ ). However, it has been set a $5 \%$ error to encompass possible interpretation mistakes of the different balance sheets (hence, the limits are, set at $35 \%$ ).

It is not applied any form of purification to capital gains, hence following the second aforementioned theory.

The weight of every component is proportional to its free-floating, with a cap set at $25 \%$ to avoid excessive concentrations. The weights are rebalanced every week, while it is hypothesized an yearly Sharia'a compliance review (so no review it is actually conducted, it would have happened in August/September 2009).

Regarding the performance analysis, it has been considered the time frame June 1st 2006 - May 31st 2009: the frame is sufficiently wide to conduct a reliable analysis and to encompass different market situations.

The chosen benchmark is the MIBTEL: although the FTSE/MIB is usually used as a representation of the Italian equity market, the high weight of mid 
and small cap made pretty useless a comparison with this index.

Dividends are not considered, in few words the portfolio is not total return.

Obviously are not considered any form of fees or expenses, it is evaluating the simple gross performance of the portfolio.

$$
\begin{gathered}
D / C=\frac{\text { total debt }}{12 \text { months average market capitalization }} \\
A R / C=\frac{\text { account receivables }}{12 \text { months average market capitalization }} \\
C a+S / C=\frac{\text { cash }+ \text { interest bearing securities }}{12 \text { months average market capitalization }} \\
\text { AbsoluteReturn }(t)^{1}=\sum_{i=0}^{t} r_{i} \\
\text { Volatility }=\sigma(\text { returns }) * \sqrt{52}
\end{gathered}
$$$$
12 m \text { Rolling Volatility }=\sigma(\text { returns last } 12 \text { months }) * \sqrt{52}
$$$$
\text { Sharpe Ratio }=\frac{\text { Absolut Return }- \text { Risk Free }}{\text { Volatility }}
$$$$
\text { Sharpe Ratio Modified }=\frac{\text { Absolut Return }- \text { Risk Free }}{\text { Volatility(AbReturn } / \mid \text { AbReturn } \mid)}
$$$$
\text { Risk Free }=\text { average 10yrs T Bill }=3.22 \%
$$$$
\operatorname{Drawdown}(t)=\max \left(1_{[0 ; t]}(i) * \text { Absolute Return }(i)\right)-r_{t}
$$

Tracking Error $($ Volatility $)=\sigma($ Portfolio Returns-Benchmark Returns $) * \sqrt{52}$

Beta $=\rho($ Portfolio Returns, Benchmark Returns $) *\left(\frac{\text { Volatility }(\text { Portfolio })}{\text { Volatility }(\text { Benchmark })}\right)$

Alpha $($ Jensen $)=($ Portfolio Return-Risk Free $)-$ Benchmark Return - Risk Free $) *$ Beta

$$
\text { Information Ratio }=\frac{\text { Alpha }}{\text { Tracking Error }}
$$

\footnotetext{
${ }^{1}$ Considered the data and the methodology utilized, It has been considered the log returns (additive across time) a more appropriate option
} 


\subsection{Stock Selection}

The first filter to apply is the one regarding haram businesses. This mean excluding all companies operating in the gambling (i.e. Lottomatica), alcohol (i.e. Campari), weapons (i.e. Finmeccanica), pork and pornography industry. A total of 6 companies have been excluded due to this provision.

Excluded are also all the companies running their businesses in a nonIslamic way: it is talking mainly about financial institutions (as Unicredit, Intesa-San Paolo, etc..) and insurance companies (as Generali). Due to this provision, 37 companies have been excluded.

It is important to underline that this provision heavily alter the strength weights in an Italian equity market dominated by these types of companies.

Then, the three filters are applied to the remaining companies. The filtering excluded other 216 companies and the result could be seen in the Table 5.1.

\begin{tabular}{|c|c|c|c|c|c|}
\hline Name & Ticker & Industry $^{1}$ & $\mathrm{D} / \mathrm{C}$ & AR/C & $\mathrm{Ca}+\mathrm{S} / \mathrm{C}$ \\
\hline Acotel & ACO.MI & Telecom & $5.72 \%$ & $6.11 \%$ & $15.00 \%$ \\
\hline $\begin{array}{l}\text { Aeroporto di } \\
\text { Firenze }\end{array}$ & AFI.MI & Transportation & $13.76 \%$ & $8.82 \%$ & $1.46 \%$ \\
\hline Bulgari & BUL.MI & Personal Goods & $24.00 \%$ & $7.24 \%$ & $1.82 \%$ \\
\hline Cembre & CMB.MI & Electronics & $30.57 \%$ & $26.89 \%$ & $4.66 \%$ \\
\hline CHL & CHL.MI & Retail & $18.30 \%$ & $14.34 \%$ & $5.94 \%$ \\
\hline Diasorin & DIA.MI & Healthcare & $14.53 \%$ & $5.45 \%$ & $1.71 \%$ \\
\hline Geox & GEO.MI & Personal Goods & $7.59 \%$ & $5.64 \%$ & $2.66 \%$ \\
\hline Gewiss & GEW.MI & Electronics & $18.19 \%$ & $16.01 \%$ & $6.81 \%$ \\
\hline Landi Renzo & LR.MI & Auto & $22.46 \%$ & $16.01 \%$ & $14.38 \%$ \\
\hline Nice & NICE.MI & Construction & $14.66 \%$ & $15.38 \%$ & $1.68 \%$ \\
\hline SAVE & SAVE.MI & Transportation & $23.83 \%$ & $5.79 \%$ & $6.58 \%$ \\
\hline Tod's & TOD.MI & Retail & $15.91 \%$ & $7.90 \%$ & $7.62 \%$ \\
\hline
\end{tabular}

1 The classification used is the FTSE Industry Classification

Out of the hundreds of companies that compose the MIBTEL, only few passed the Islamic filters. As we aforementioned this is connected to the structure of Italian companies, the debt as main financing source nearly al- 


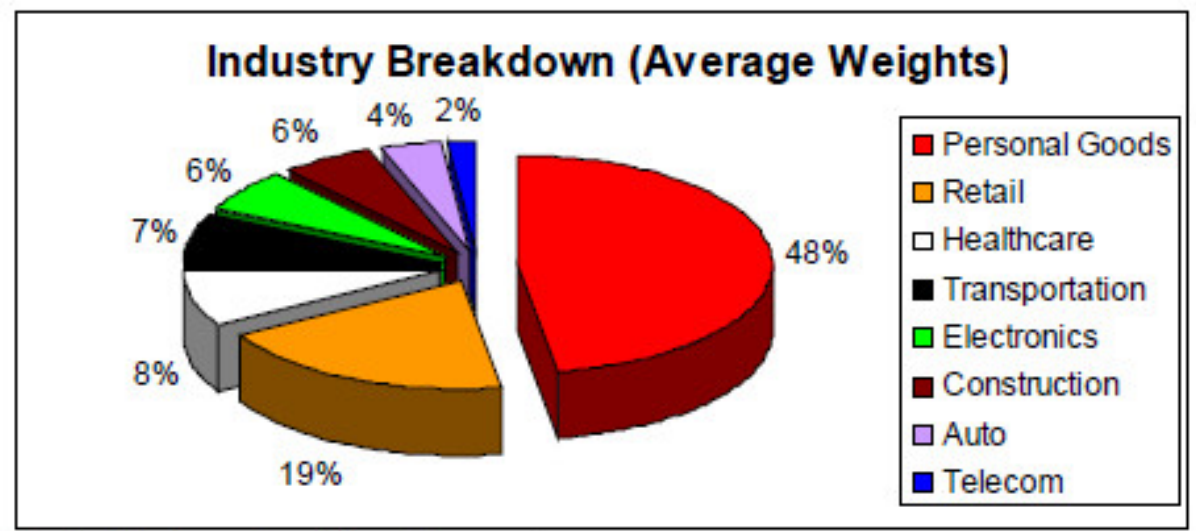

Graph 5.1 - Sector Breakdown (Average)

ways rule out Italian companies when applying financial ratios provisions. The most evident result (Graph 5.1) is the deeply different industry breakdown, particularly compared to the FTSE/MIB dominated by banks, energy companies and utilities.

While the main index represents the strength weights existent in the Italian corporate world, the resulting portfolio seems representing the Italian excellences. Over $65 \%$ is composed of companies operating in one of the most acclaimed sector of the Made in Italy: fashion. An additional $7 \%$ is represented by the companies that manage the airports of two of the main Italian tourist hubs: Venice (SAVE) and Florence/Tuscany (AdF). In few words, nearly $3 / 4$ of the portfolio represents Italian "diamonds": the only excluded sector seems food\&drinks, mainly due to haram provisions. 


\subsection{Absolute Performance}

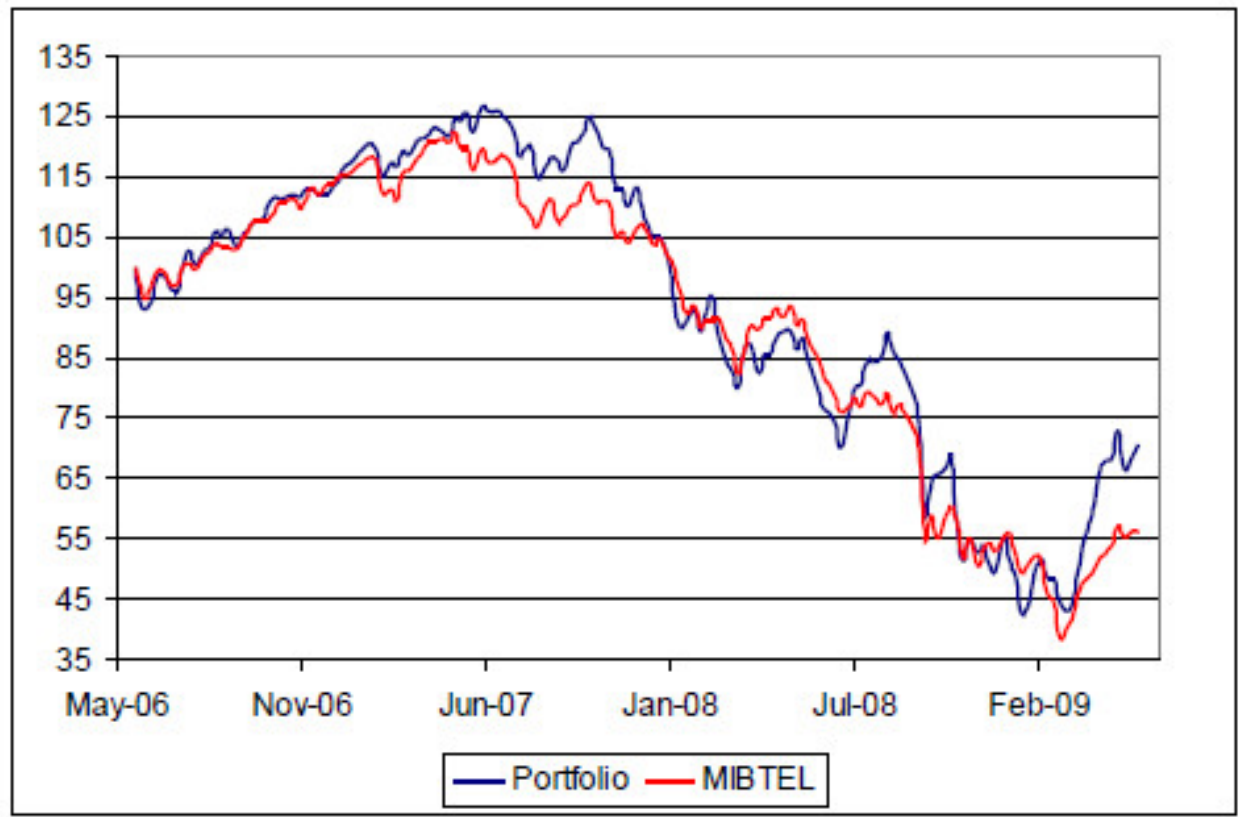

Graph 5.2 - Value $(100=$ value on June 1st 2006)

The behaviour of the portfolio is without any doubt peculiar, however it is possible to identify six different moments:

- 2006 In this strong growth period the portfolio nearly followed the benchmark, the average return is just around 5 bps below the benchmark.

- gen-oct 07 In this period the benchmark and the portfolio reached their respective peaks. The portfolio behaved better than the benchmark with an average return 21 bps above the MIBTEL.

- nov 07 - may 08 This period has been signed by the beginning of the crisis and the downside movement of the market. The portfolio average return is nearly 35 bps below the benchmark.

- jun 08 - feb 09 The peak of the crisis has been characterized by an average portfolio return nearly 30 bps above the benchmark.

- mar-jun 09 The market started to grow again and the portfolio registered an average return nearly 120 bps above the MIBTEL. 
It is clearly not easy to interpret this behaviour. However it seems that the portfolio behave better in "critical" periods (boom or crisis peaks, fast growth, etc..), while it underperforms the benchmark when the market is moving in a more "quiet" way.

This can be partially explained by the great weight of the personal goods sector (DJ STOXX Personal Goods TMI), that during these periods showed movements similar to the portfolio behaviour (although higher, due to the fact the European market generally reacted better than the Italian one).

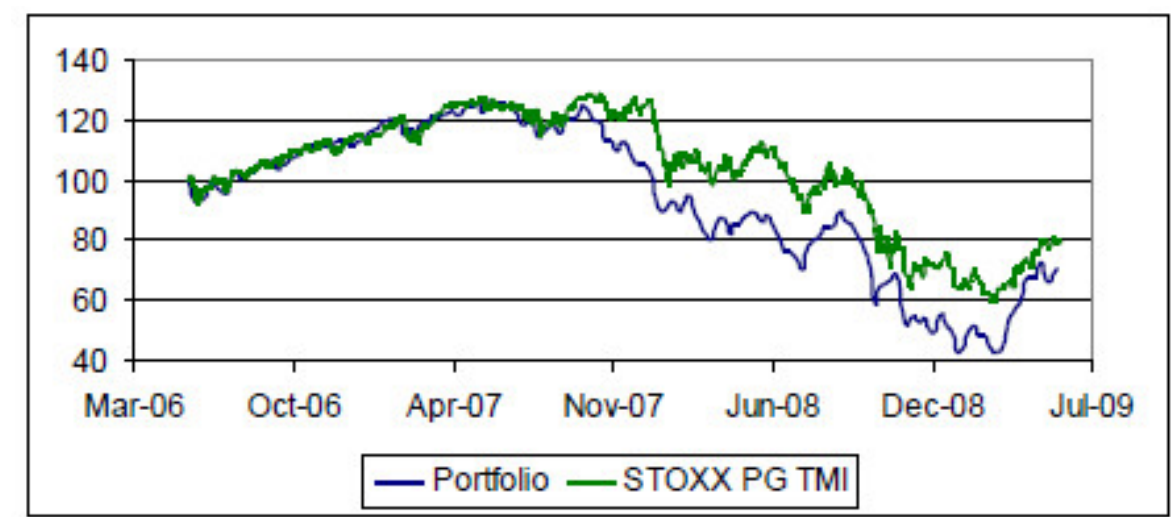

Graph 5.3 - Value $(100$ = value on June 1st 2006)

\subsection{Absolute and Relative Risk}

\begin{tabular}{|c|c|c|c|c|c|c|c|c|c|c|c|c|}
\hline & & CE & $\mathrm{cH}$ & GEV & $=$ & A & C & GEC & 10 & & LR & I. \\
\hline $\mathrm{CMB}$ & 1,00 & 0,32 & 0,43 & 0,40 & 0,23 & 0,02 & 0,49 & 0,32 & 0,40 & 0,28 & 0,49 & 0,17 \\
\hline NICE & 0,32 & 1,00 & 0,37 & 0,36 & 0,38 & $-0,06$ & 0,24 & 0,32 & \begin{tabular}{|l|}
0,40 \\
\end{tabular} & \begin{tabular}{|l|}
0,45 \\
\end{tabular} & 0,22 & 0,04 \\
\hline$\overline{\mathrm{CHL}}$ & 0,43 & 0,37 & 1,00 & $\overline{0,41}$ & 0,31 & 0,03 & 0,30 & 0,24 & 0,32 & \begin{tabular}{|l|}
0,37 \\
\end{tabular} & 0,32 & 0,09 \\
\hline GEW & 0,40 & 0,36 & 0,41 & 1,00 & 0,31 & 0,05 & 0,21 & 0,17 & \begin{tabular}{|l|l|}
0,21 \\
\end{tabular} & \begin{tabular}{|l|}
0,27 \\
\end{tabular} & 0,19 & 0,0 \\
\hline SAVE & 0,23 & 0,38 & 0,31 & 0,31 & 1,00 & 0,08 & 0,19 & 0,26 & 0,25 & \begin{tabular}{|l|}
0,37 \\
\end{tabular} & \begin{tabular}{|l|l}
0,14 \\
\end{tabular} & {$[0$,} \\
\hline AFI & 0,02 & $-0,06$ & 0,03 & 0,05 & 0,08 & 1,00 & $-0,04$ & $-0,03$ & 0,09 & \begin{tabular}{|l|}
0,06 \\
\end{tabular} & $-0,01$ & 0,19 \\
\hline$\overline{A C O}$ & 0,49 & 0,24 & 0,30 & 0,21 & 0,19 & $-0,04$ & 1,00 & 0,28 & \begin{tabular}{|l|}
0,31 \\
\end{tabular} & 0,28 & 0,35 & 0,1 \\
\hline GEO & 0,32 & 0,32 & 0,24 & 0,17 & 0,26 & $-0,03$ & 0,28 & 1,00 & \begin{tabular}{|l|}
0,51 \\
\end{tabular} & \begin{tabular}{|l|}
0,59 \\
\end{tabular} & 0,22 & 0.0 \\
\hline TOD & 0,40 & 0,40 & 0,32 & 0,21 & 0,25 & 0,09 & 0,31 & 0,51 & 1,00 & \begin{tabular}{|l|}
0,46 \\
\end{tabular} & \begin{tabular}{|l}
0,35 \\
\end{tabular} & 0,1 \\
\hline BUL & 0,28 & 0,45 & 0,37 & 0,27 & 0,37 & 0,06 & 0,28 & 0,59 & \begin{tabular}{|l}
0,46 \\
\end{tabular} & 1,00 & 0,24 & 0,02 \\
\hline 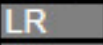 & 0,49 & 0,22 & 0,32 & 0,19 & 0,14 & $-0,01$ & 0,35 & 0,22 & \begin{tabular}{|l|l}
0,35 \\
\end{tabular} & 0,24 & 1,00 & 0,17 \\
\hline$\overline{\mathrm{DAA}}$ & 0,17 & 0,04 & 0,09 & 0,00 & 0,11 & 0,19 & 0,10 & 0,05 & 0,10 & \begin{tabular}{|l|}
0,02 \\
\end{tabular} & $\begin{array}{ll}0,17 \\
\end{array}$ & 1,0 \\
\hline
\end{tabular}

Table 5.2 - Correlation Matrix

A first observation regarding the risk of the portfolio can be made observing the correlations matrix (Table 5.2). Although the limited number of stocks could create some problems regarding the diversification, the selected stocks have quite low correlations with other ones. The major problem could 
be found in the pretty high correlations existent among Geox, Tod's and Bulgari, three stocks representing around $70 \%$ of the portfolio.

A (rough) diversification measurement could be performed through the Fama's measure: the slightly negative value (-0.014) suggests that there are no critical diversification problems.

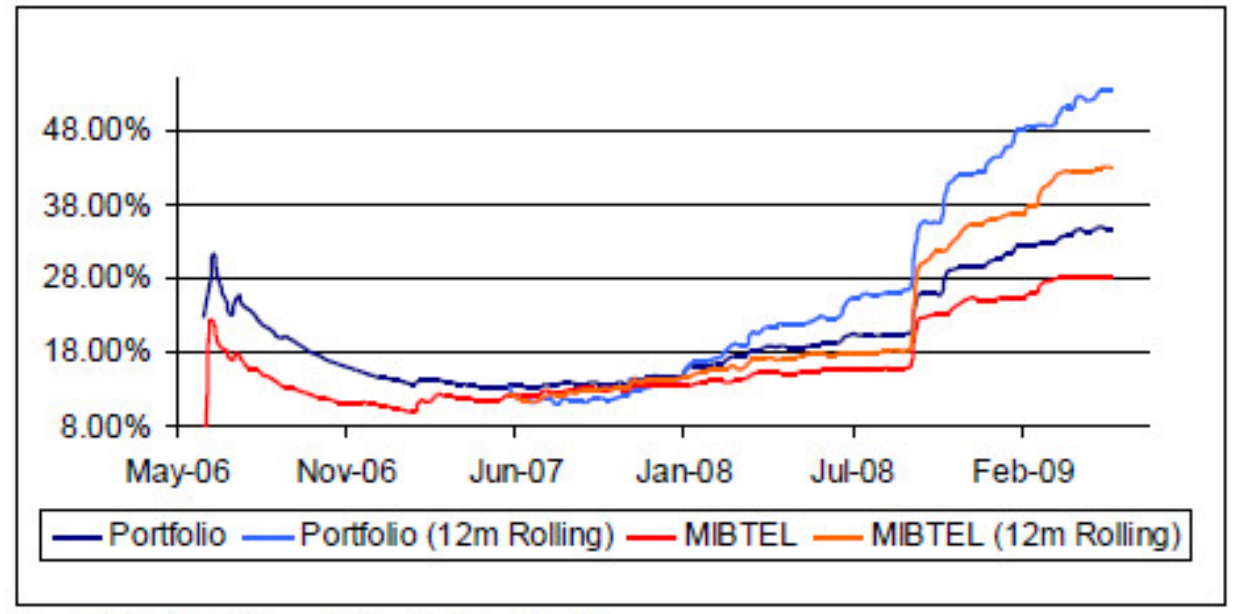

Graph 5.4 - Volatility and $12 \mathrm{~m}$ Rolling Volatility

It is evident that the volatility of the portfolio (Graph 5.4) is systematically above the benchmark one. Only in the H2 2007 the gap narrow down and the 12-months rolling volatility decline below the MIBTEL one.

Differently from what we aforementioned regarding Islamic equity funds, the Italian Islamic equity portfolio is actually MORE risky than an investment in the market index.

However, looking at the drawdown, the portfolio looks not so more risky: in fact the maximum drawdown $(-109.66 \%)$ is below the maximum drawdown of the benchmark (-116.31\%).

As we mentioned in the sub chapter above, although characterized by an higher volatility, the Islamic portfolio "navigated" better the crisis.

Overall, it seems that the portfolio performance compared to the benchmark is somewhat linked to the volatility (Table below): the three periods characterized by higher returns correspond to minimal or negative absolute differences in volatility growth, while the two characterized by lower returns correspond to higher absolute differences in volatility growth. When the risk of the portfolio is growing at similar or lower pace than the benchmark, the portfolio performs better, when the risk is rising at a brisker pace, the portfolio tend to underperform. In few words, the portfolio does not transform properly the additional risk in additional returns.

The beta (Graph 5.5) clearly shows the existence of a strong relation- 


\begin{tabular}{|c|c|c|c|}
\hline Period & $\begin{array}{c}\text { Return Difference } \\
\text { (absolute bps) }\end{array}$ & $\begin{array}{c}\text { Return Difference } \\
\text { (relative) }\end{array}$ & $\begin{array}{c}\text { Volatility Growth } \\
\text { Difference }\end{array}$ \\
\hline 2006 & $-5.23 \%$ & $-11.60 \%$ & $+17.24 \%{ }^{1}$ \\
\hline Jan - Oct 2007 & $+20.76 \%$ & $>100 \%$ & $-25.92 \%$ \\
\hline Nov 07 - May 08 & $-36.74 \%$ & $-56.20 \%$ & $+16.64 \%$ \\
\hline Jun 08 - Feb 09 & $+28.28 \%$ & $+15.30 \%$ & $+5.07 \%$ \\
\hline Mar - Jun 09 & $+118.75 \%$ & $+67.60 \%$ & $+3.76 \%$ \\
\hline
\end{tabular}

1 In 2006 both volatilities are decreasing, but portfolio one at a lower pace

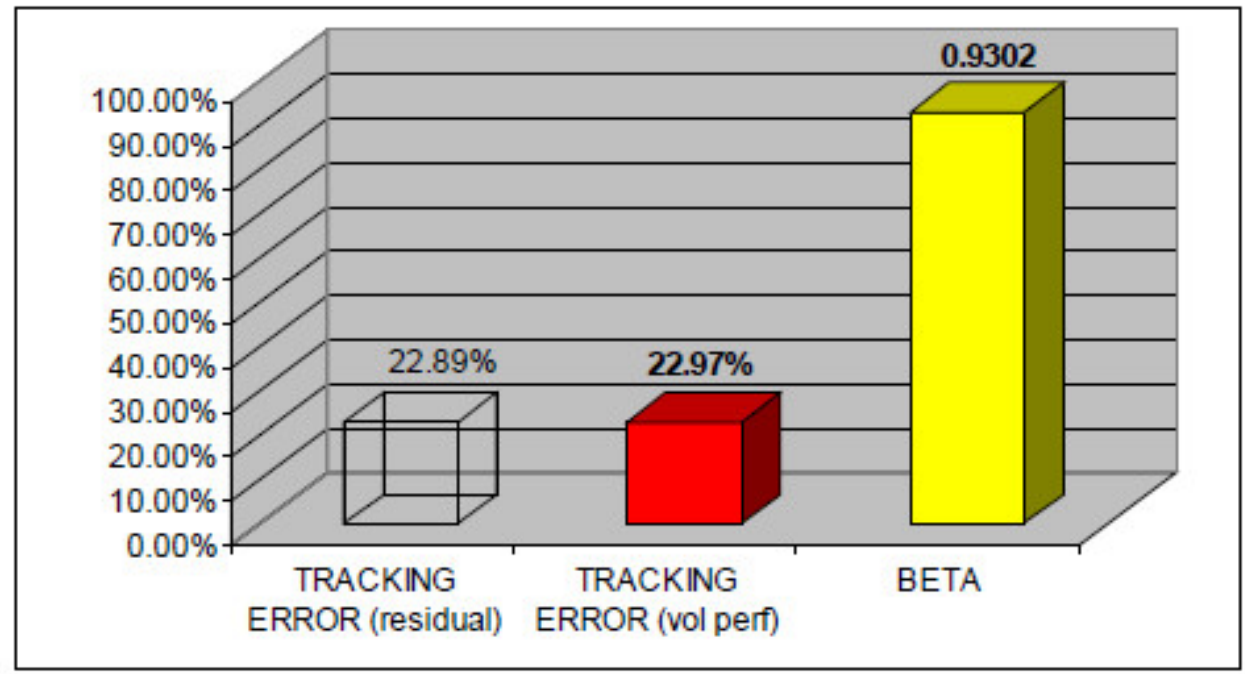

Graph 5.5 - Relative Risk Measures

ship between the portfolio and the market, besides the nearly unitary value validate the fact that the portfolio does not actually amplify or reduce the market movements.

However the tracking error shows the existence of a significant variability in the movements from the benchmark: while the long-term trend follows the MIBTEL, the actual periodical movements are characterized by a nonconstance.

It is clear that the additional risk of the portfolio is specific risk; in fact the systematic risk is pretty much the same of the market. This tells that, although what we obtained using the Fama measurement, there are actually some diversification problems.

\subsection{Risk-Adjusted Performance}

While absolute returns and risk measurement are essential in a portfolio analysis, without any doubt it is the evaluation of the risk-adjusted performance 
that ultimately reveal the overall quality of the product.

Without any doubt, the Sharpe ratio is one of the most powerful measurement of the portfolio performance.

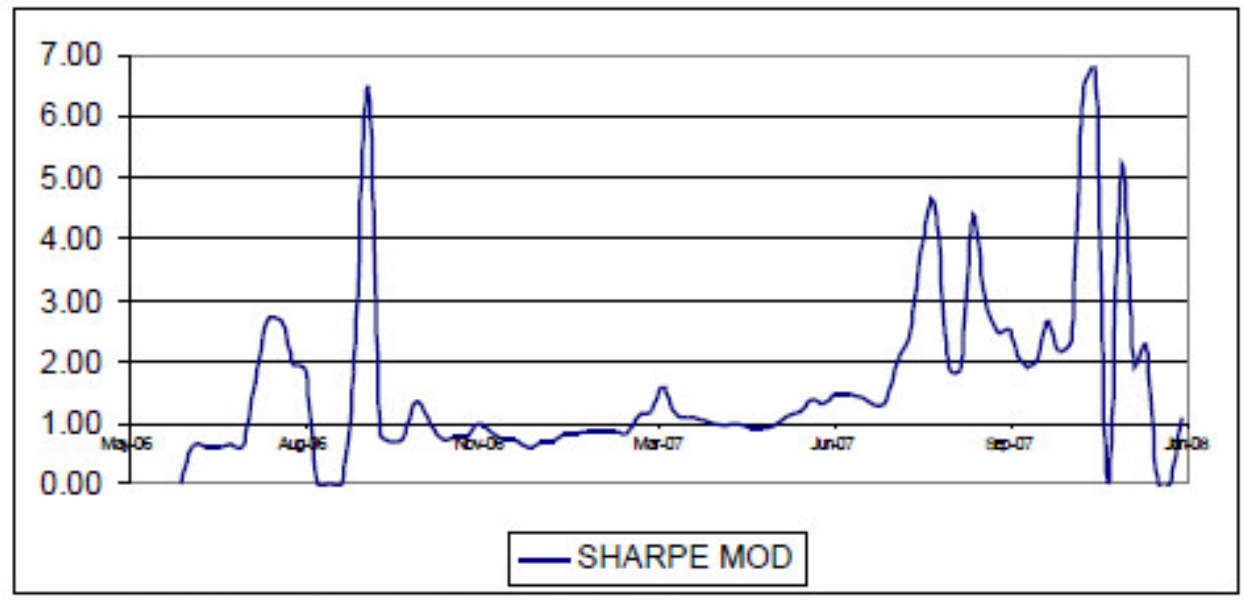

Graph 5.6 - Portfolio/MIBTEL Sharpe Indexes Ratio

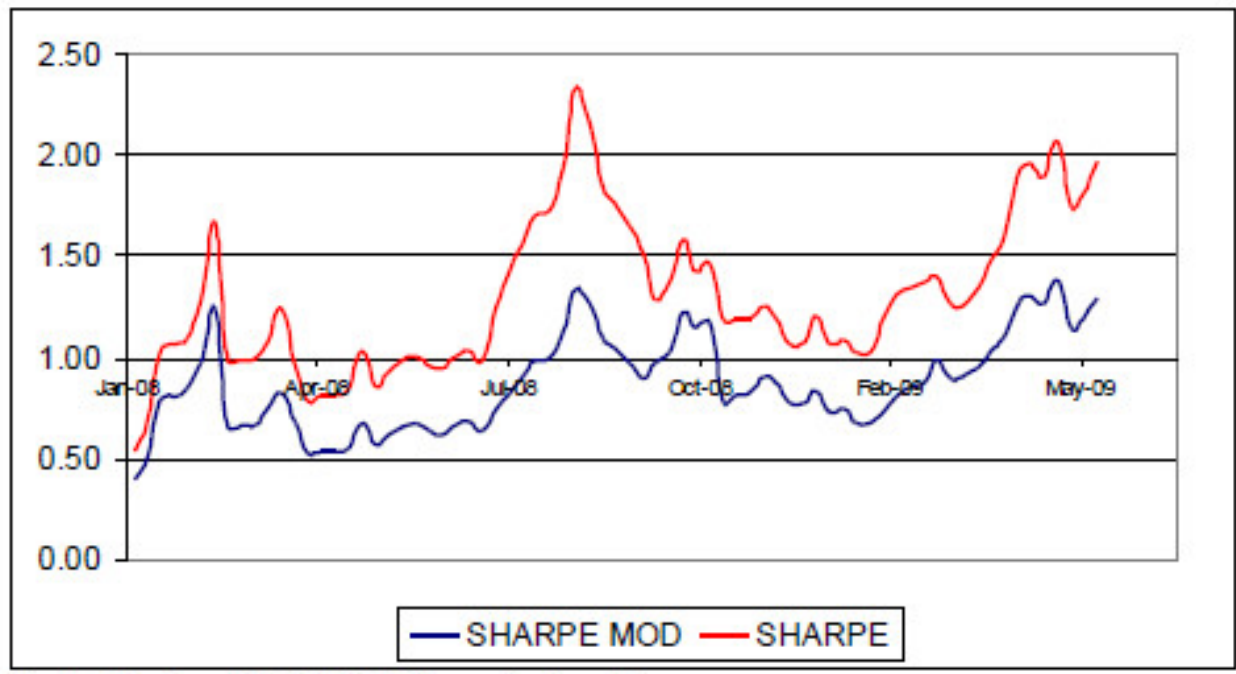

Graph 5.7 - Portfolio/MIBTEL Sharpe Indexes Ratio

The charts above shows the ratio between the portfolio and MIBTEL Sharpe ratios (if above one, it means that the portfolio Sharpe ratio is higher); when adventuring in the discussed ( $\S$ Appendix) problem of negative ratios, it is shown both the modified and the standard ratio.

The result is pretty much specular to what it has been obtained in the analysis of the absolute performance. However the period of outperforming looks narrower: during the early 2007 the portfolio ratio was below the MIBTEL, 
the same during part (Nov 08 - Mar 09) of the crisis.

The scenario is a bit different if considering the "standard" Sharpe ratio, in this case the portfolio shows a way higher performance during the peak and the (supposed) recover of the crisis (since mid-July 08 the portfolio Sharpe ratio has been constantly above the benchmark one) and not a so lower one during the crisis beginning (1H 2008).

Another interesting point of view to considered is the Alpha and, so the information ratio. While the Sharpe ratio is useful to compare the portfolio with the market benchmark after adjusting with the respective risks, the Alpha (in this case it has been used the Jensen Alpha) reveals if the portfolio has actually beat the market.

The result is in this case promising: the $12.11 \%$ Alpha clearly and definitely reveals that in the considered period the portfolio performed better than the MIBTEL.

Although more useful to compare different portfolios, also the information ratio could be useful. The calculation tells that for every unit of additional risk (measure by the tracking error), the portfolio provide 0.53 units of additional profit: without doubts a quite good results.

\subsection{Remarks}

Without doubts the results obtained analysing the Islamic Italian Equity portfolio looks quite unexpected.

Although there have been the problems connected with the sharia'a compliance of debt-focused companies, other characteristics typical of Islamic equity funds seems missing. The most evident is the riskiness: while this type of funds usually shows a low risk, the considered portfolio is actually riskier than the market. This characteristic is, however, paired with a (absolute and adjusted) higher performance.

The former could be explained by the important weight in the portfolio of mid/small-caps marked by high volatilities: CHL, Acotel, Aeroporto di Firenze and SAVE all show values higher than $60 \%$. The latter could be explained by the financial ratios that isolated companies with very good book values and, generally, representing Italian sector and single excellences.

Without any doubts the absence of financial stocks is partially responsible for the better performance, but the total absence of energy companies clearly differentiate this portfolio from other Islamic funds it has been observed. All these characteristics lead to an extremely significant conclusion: the Islamic Italian equity portfolio is a totally different product from other Islamic 
equity ones. The other (US, Global, etc..) products are a safer investment than investing in the market, this mainly because the ratios isolate financially solid and with low volatility companies (usually blue-chips).

The Italian one caters to a different category of investor, investors that accept a higher risk to invest in "gems": in few words, the Islamic portfolio offers an extremely competitive trade-off between alpha and risk. 


\section{Conclusions}

Looking at the results obtained in this paper, it is possible to identify three main points.

The first main point is that, although the industry has been severely hit by the crisis, it has still a big growth potential. This is thanks to two important variables: the strong presence in countries with minimally developed financial systems and the economical implications of the Islamic provisions. The focus on countries as India, Malaysia, Indonesia or Turkey allows the Islamic equity funds industry to penetrate markets with limited competition. In these countries there is a growing middle-class, while the offering of investment products is still limited; clearly Islamic funds have the possibility to gain a considerable share of the market, thing that it is impossible where traditional funds are widely available. Another important characteristic is that the religious provisions imply some economically rational guidelines: all the financial ratios are measurements very similar to the ones used by traditional stock pickers. Obviously, this is something very rare among ethical funds: except some green funds investing in high-risk/high-reward high-techs companies, the majority has stock picking guidelines without any particular economical rationale.

These considerations should also be useful for ethical investments operators in the Western world, in fact many of the Islamic provisions are (or better were) present in the Christian doctrine (usury, gambling, pornography, etc..). The idea of a Christian Equity Fund is quite non-sense, but this point deserve a major analysis: there are many emerging markets (i.e. Brazil and Mexico) or areas (i.e. some parts of the USA) where Christian values and morale are still strongly rooted in the community and where there could be market opportunities for properly repackaged Islamic equity funds.

The second point traces back to the discussion about the risk and performance characteristics of Islamic equity funds. The brief analysis conducted (§ Appendix) generally agrees with the most recent studies (particularly the one of Kraeussl and Hayat): Islamic equity funds offer a safer investment opportunity and that is able to better face market shocks.

Besides, the most recent products show an alleviation of the traditional problems connected to this type of funds: price and diversification.

These characteristics definitely isolate the Islamic equity funds as a particular and independent category of funds investment: a perfect instrument for medium to long-term investors looking for a not particularly risky equity 
investment.

This is without doubt another point behind the industry success and future potentialities: the risk/return structure is particularly suitable to middleclass/mass affluent clients and generally conservative institutional or quasiinstitutional clients (as pension funds or endowments), the formers have been the main fuel of the mid 2000s boom and the latter will probably be the keymarket in the future.

Remaining in this area, an additional interesting result is the one regarding ETFs. Although they are able to offer Islamic equity products at a fraction of the price requested by mutual funds, they could be collocated in a totally different area. In fact Islamic ETFs are characterized by an higher risk than Islamic mutual funds, characteristic that is not present in the comparison between traditional ETFs and mutual funds. Islamic ETFs are actually a better choice only for short-term investors that are willing to accept the way higher risk. It is evident that there is little risk that the ETFs will cannibalize Islamic mutual funds, they should be a complimentary product mainly suitable to clients with large and diversified portfolios (as HNWIs and UHNWIs).

Last but not least are the considerations regarding the Italian equity market and Italian financial institutions.

Connections between Italy and the Muslim worlds date back to the IX century, when part of the southern part of the peninsula was ruled by Arabs. Recently Muslims have started to invest capitals in Italy (e.g. Unicredit), particularly Libic investors. Besides, Italian financial institutions are expanding in the Muslim world: Intesa SanPaolo is directly present in Albania, Bosnia, Egypt and UAE, Unicredit in Azerbaijan, Bosnia, Kirghizistan and Turkey.

However both internal and external operations are still minimal compared to the existent potential: partially due to law restrictions, partially due to a, mainly social and political, mistrust climate grown in the last 10-15 years.

A major constraint to the born of this industry is without doubts also the law: Italian civil, commercial and banking law still clashes with some Islamic principles making some operations impossible or very difficult. However, this particular framework clearly offers interesting internal and external opportunities for Italian financial institutions.

And the peculiar results of the conducted analysis clearly indicates a path to follow.

Problems regarding the compliance of Italian companies were obviously expected: in Italy the fiscal system greatly favours the financing through debt. This is partially responsible for the very small number of companies that 
actually passed the Islamic filters.

The most evident surprise is the digression from what could be considered the norm among Islamic equity funds: the portfolio is riskier than the market.

This clearly place the portfolio in a unique position among peers, a product able to offer an interesting risk/return combination not very common among other Islamic equity funds.

As it has been aforementioned, this is probably strongly linked to the uncommon composition of the portfolio, a portfolio dominated by the retail and personal goods sector. The portfolio, in few words, offers the opportunity to invest in some of the most acclaimed sector of the Made in Italy, while following the Islamic provisions.

The main targets of operations in Islamic countries should clearly be the middle-class/mass-affluent segment, which could be easily reached through the existent network of branches that some Italian banks have in these countries. Some of these countries, as Turkey and Egypt, have nearly undeveloped Islamic finance industries and minor Islamic equity funds offerings, but a big or even huge potential client base. Italian banks and AMs could leverage their presence and the political/economical superior relations to enter and develop this lucrative market.

Different is the strategy regarding operations in the Italian equity market: the underlined uniqueness of the portfolio clearly offers an interesting and competitive opportunity to Italian players. Italian financial institutions would be able to offer products based on Italian equities that could be used in large portfolios as the ones of HNWIs, pension funds or even funds of funds. The different characteristics compared to other Islamic equity products, clearly offer these (quasi) institutional investors the opportunity to develop more diversified portfolios mainly in terms of risk and sector breakdown.

This strategy can be implemented through the existent subsidiaries that Italian companies have in Islamic countries, through in-house structures built in Italy or through partnerships/join ventures with local players that lack the scale and/or the technical skills to deal with big institutional investors.

On the other hand, there are obviously the opportunities in the internal Italian market. What is evident is that although there are great potentials, the hypothetical client base is still "raw" (small middle-class, financially illiterate, etc..) and the Italian equity market offers solutions not very suitable to a mainly conservative and risk adverse investor class. So, the Italian market would be more suitable to financial institutions with a established presence in the industry or to Italian ones when they will have acquired sufficient experience.

However, the implementation of basic banking services would be able to at- 
tract an often young customer base and raise the interest and knowledge among second/third generation Muslims in Islamic finance products: this could be clearly the base for a future (10-15 years) introduction of the Italian focused products.

Without any doubt the Islamic equity funds industry has still great growth potentials and, obviously, they lie mainly in developing Islamic countries. Without any doubt the industry has seen the entrance of financial giants as UBS, DB, Allianz or the American IBs that clearly want to get their juicy big slice of the cake. Without any doubts it is still a business that requires higher expenses, investments and a lot of political pressure.

But all this should not be an obstacle to Italy, Italian companies and Italian financial institutions to benefit from this opportunity.

The Italian players already have an extensive experience in emerging markets (as in the CEE) and the ties with the Islamic world have always been stronger than other countries (this is the reason why France banks are succeeding more than American heavy-weights).

It only requires the willingness to invest money in this sector, it only requires the political and cultural willingness to the diffidence and animosity rose in the last decade: then, there will be no limit. 


\section{A Funds Comparison}

One of the most discussed characteristic of Islamic equity funds is their performance compared to traditional products. The matter is actually quite recent, due to the short history of this industry (Kraeussl and Hayat, 2008), and the results have been quite different.

Studies that have used 1997-2001 data (Abderrezak, 2008) reached negative conclusions regarding Islamic equity funds: inferior relative and absolute performances and limited diversification. Other studies (Kraeussl and Hayat, 2008) that have used more recent data (2001-2006) reached different conclusions: although Islamic equity funds have several (and critical) problems, they offer a safe haven during bear markets (particularly thanks to a systematically lower Beta).

\section{A.1 Methodology}

In this section a systematic analysis will not be conducted: this is not the objective. The data are not widely available and the youth of the phenomenon make a complete analysis heavily biased (funds choice, data available, etc..). Indeed, we are particularly interested in observing the behaviour during the financial crisis.

The decision to choose Global Equity funds and ETFs has the goal to consider highly liquid funds and that generally not represents a particular geographical area. Obviously if it had been considered funds with a specific geographic focus, the result could have been different. The choice of the two Islamic products has been guided by the dimension and the importance of the financial institution: the UBS product is a big and extremely popular fund with a long history of analysis (practically it appears in every research, study, etc...), the Allianz fund is way smaller but represents one of the latest products offered before the crisis by a major AM player.

The ETF choices are inevitably the iShares products (without doubts one of the biggest player in this field).

The choices regarding the pool of traditional funds follow a pattern similar to the Islamic one: we focused on big funds with a long enough history and offered by major players. However, we have also focused on obtaining a pool of both European and American asset managers and funds with different investment strategies (some passive and some active).

The data used are from 17/06/2008 to 17/06/2009 and has been obtained from the corporate websites and/or financial data providers (mainly Reuters). The data regarding the composition of funds has been obtained from the latest available prospectuses. 


$$
\begin{gathered}
\text { AbsoluteReturn }(t)^{2}=\sum_{i=0}^{t} r_{i} \\
\text { Volatility }=\sigma(\text { returns }) * \sqrt{252} \\
\text { Sharpe Ratio }=\frac{\text { Absolut Return }- \text { Risk Free }}{\text { Volatility }} \\
\text { Sharpe Ratio Modified }=\frac{\text { Absolut Return }- \text { Risk Free }}{\text { Volatility } \text { (AbReturn/|AbReturn } \mid)}
\end{gathered}
$$

$$
\text { Risk Free }=\text { average 10yrs T Bill }=3.22 \%
$$

Max $/$ Min $=$ Maximum $/$ Minimum absolute return during holding period

Beta $=\rho($ Portfolio Returns, Benchmark Returns $) *\left(\frac{\text { Volatility }(\text { Portfolio })}{\text { Volatility }(\text { Benchmark })}\right)$

$$
\text { Benchmark }=\text { MSCI World }
$$

\footnotetext{
${ }^{2}$ The values obtained using this formula are practically equal (the difference is always less than 1-2 bps) to the ones that could be obtained using the more correct formula $(1+\mathrm{r} 1) *(1+\mathrm{r} 2) *(1+\mathrm{r} 3) . . *(1+\mathrm{rn})$
} 


\section{A.2 Global Equity Mutual Funds}

\section{ALLIANZ RCM GLOBAL EQUITY OPPORTUNITIES A USD}

\section{ISIN:}

Launch Date:

Net Assets:

Front End Load:

Management Fee (p.a.):

Abs Return:

Max/Min:

Volatility:

Sharpe Ratio:

Sharpe Ratio (mod):

Beta:

\section{LU0356362771}

$22 / 07 / 2008$

$43 \mathrm{mln}$ USD (30/04/2009)

$$
5.00 \%
$$

$1.50 \%(\max 2.50 \%)$

$-27.00 \%$

$+0.39 \% /-40.74 \%$

$29.34 \%$

$-0.86$

$-0.11$

0.23

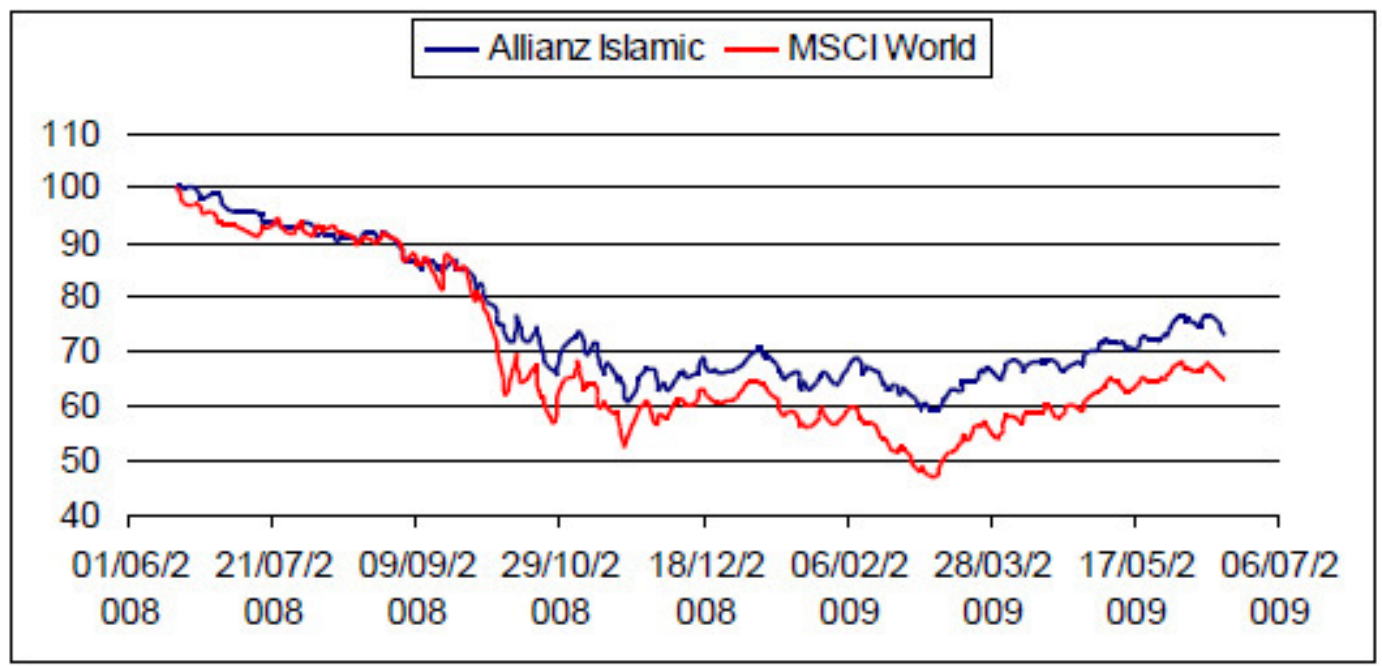

Graph A.1 - Value (100 = value on June 17th 2008) 


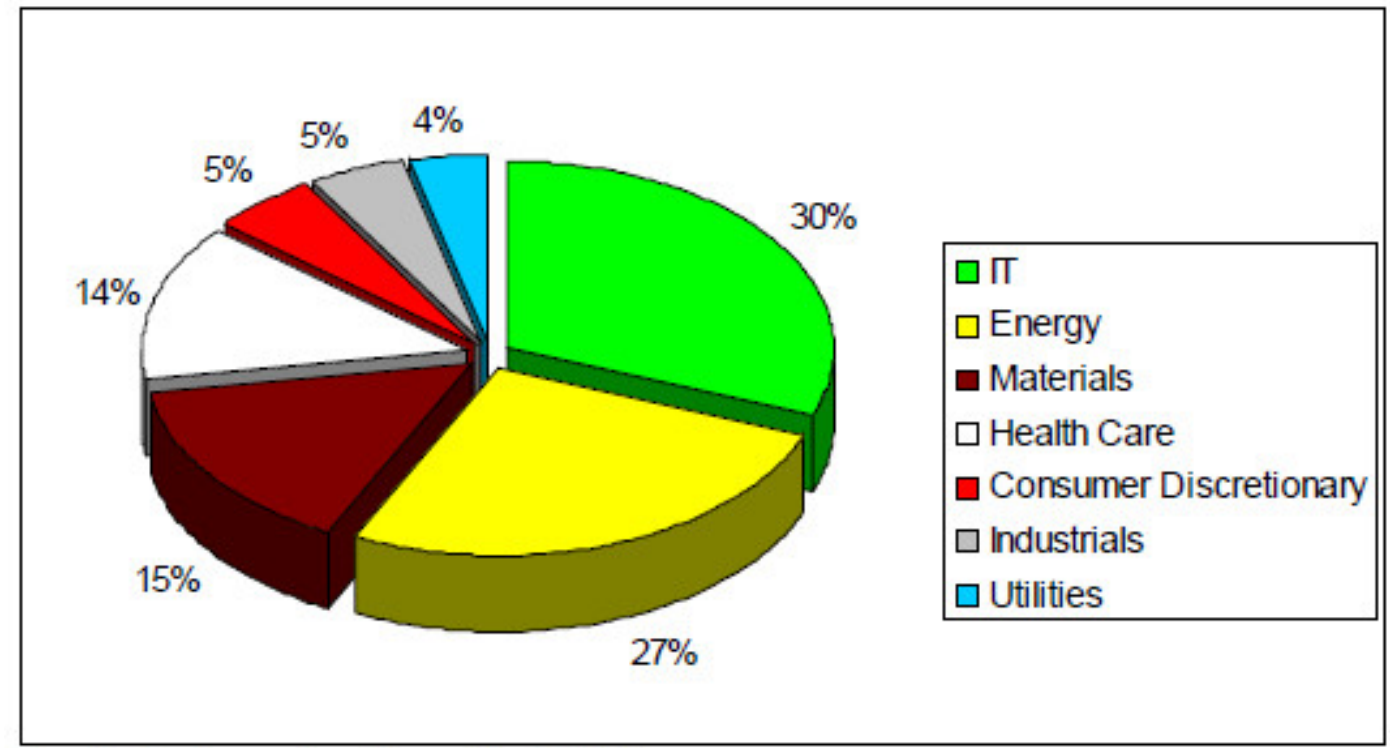

Graph A.2 - Sector Breakdown (April 2009)

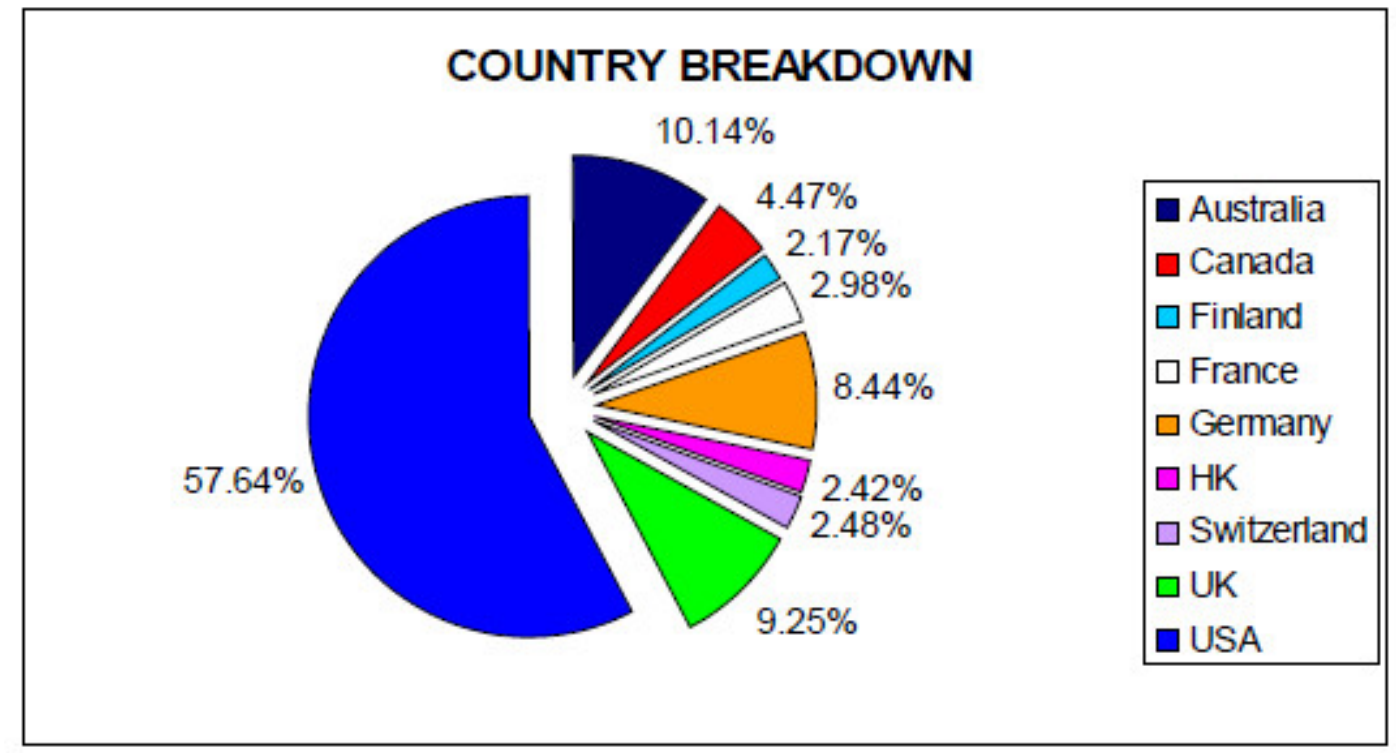

Graph A.3 - Country breakdown (April 2009) 


\section{UBS ISLAMIC FUND - GLOBAL EQUITIES}

ISIN:

Launch Date:

Net Assets:

Front End Load:

Management Fee (p.a.):

Abs Return:

Max/Min:

Volatility:

Sharpe Ratio:

Sharpe Ratio (mod):

Beta:
LU0108058487

$19 / 05 / 2000$

$337 \mathrm{mln}$ USD $(30 / 05 / 2009)$

$6.00 \%$

$2.04 \%$

$-25.48 \%$

$-0.76 \% /-41.64 \%$

$35.28 \%$

$-0.68$

$-0.12$

0.93

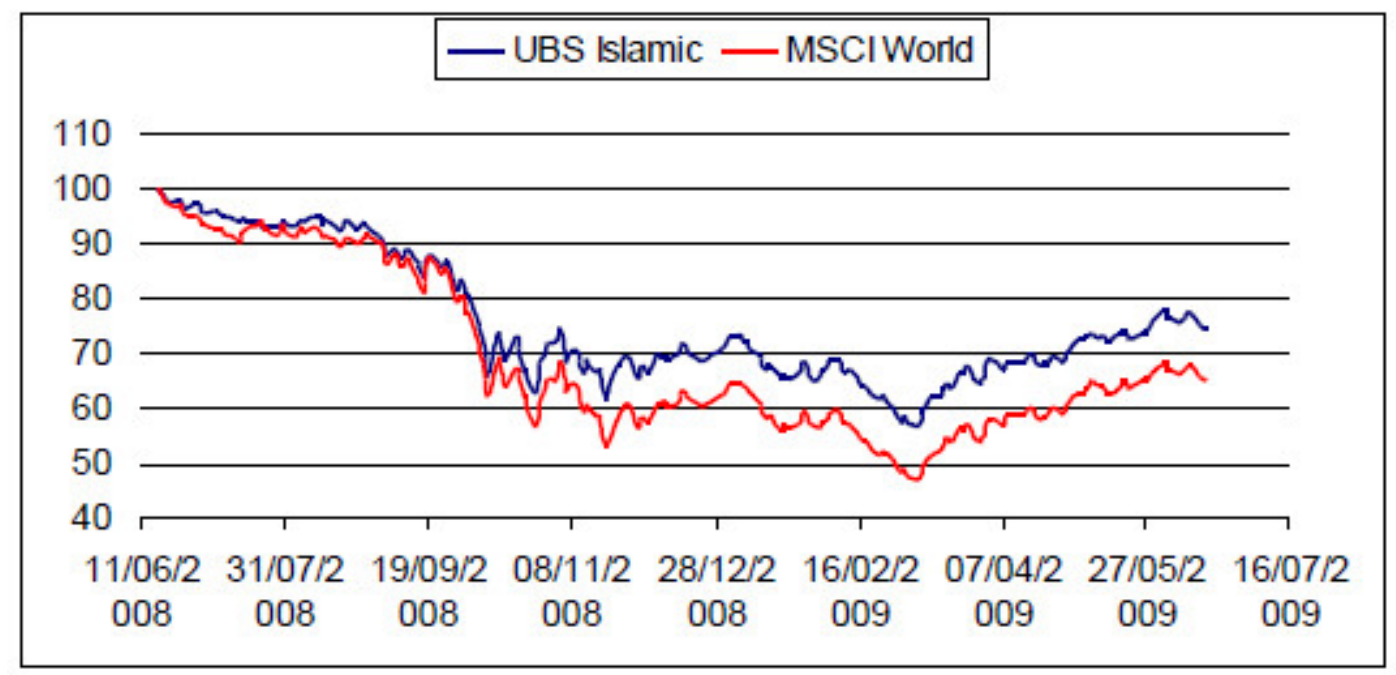

Graph A.4 - Value (100 = value on June 17th 2008) 


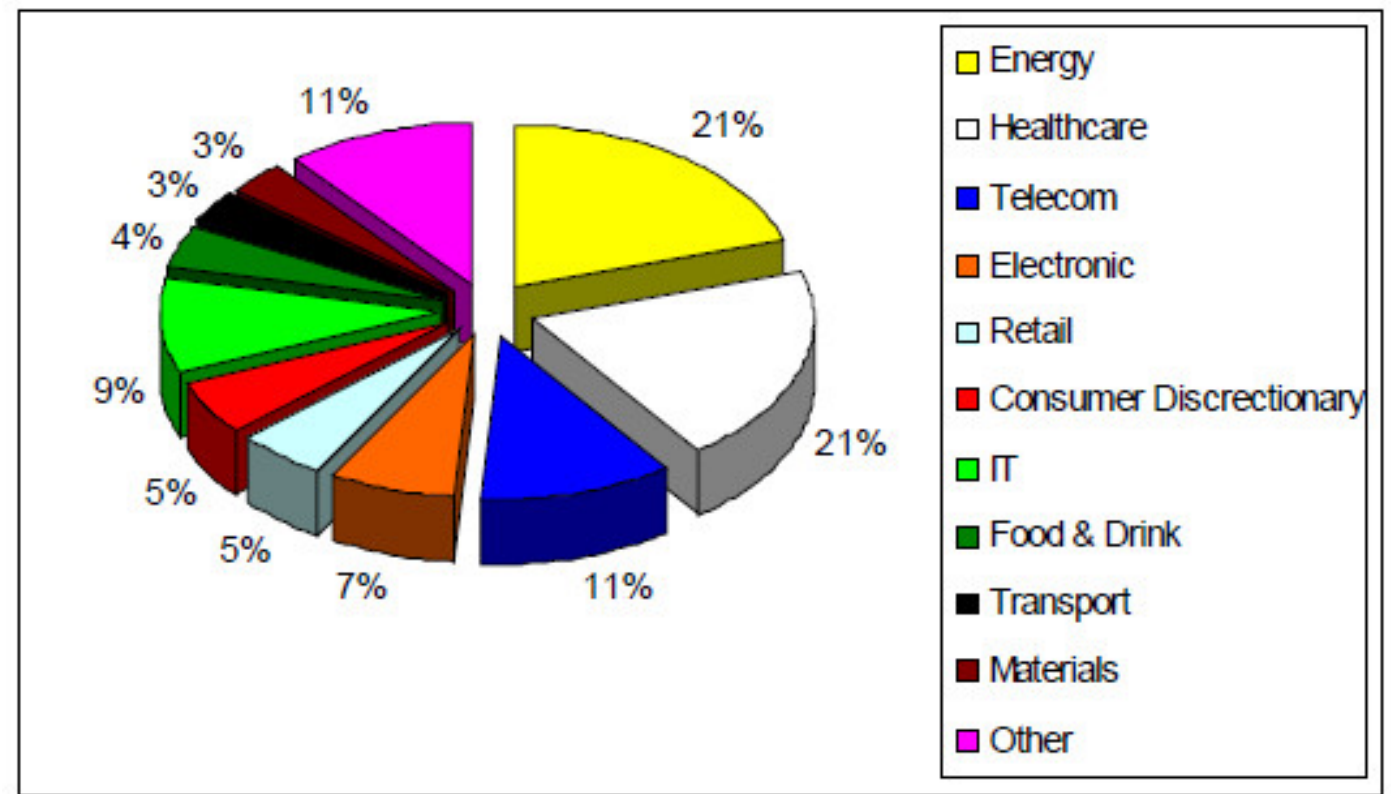

Graph A.6 - Sector Breakdown (May 2009)

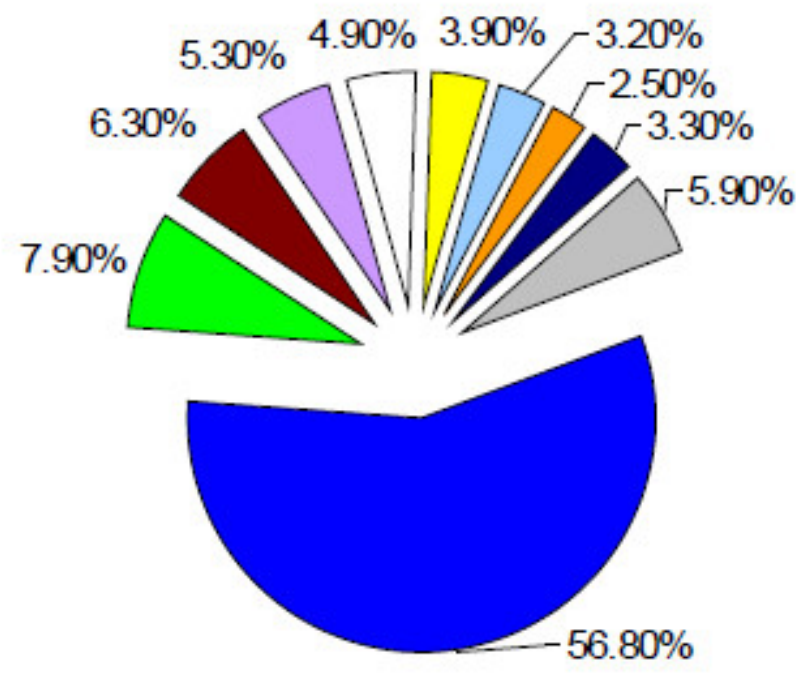

- USA

$\square$ UK

- Japan

$\square$ Switzerland

$\square$ France

$\square$ Taiwan

$\square$ Luxembourg

$\square$ Germany

- Australia

$\square$ Others

Graph A.5 - Country Breakdown (May 2009) 


\section{POOL}

Funds:

verage Front End Load:

Average Management Fee (p.a.):

Average Abs Return:

Average Volatility:

Average Sharpe Ratio:

Average Sharpe Ratio (mod):

Average Beta:
Templeton Equity Income

Alliance Bernstein Global Equity Blend

GS Global Equity Portfolio

JPMG Global Equity

Schroder Global Equity Alpha

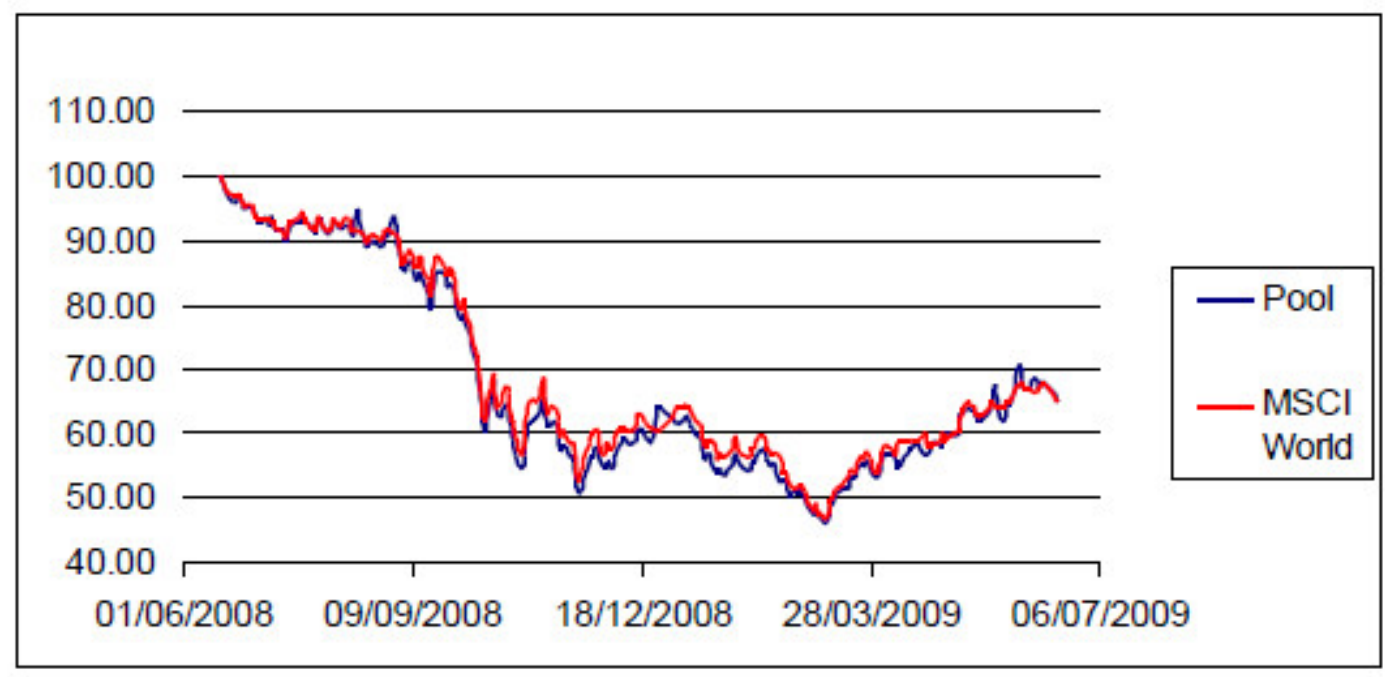

Graph A.7 - Average Value $(100=$ value on June 17th 2008) 


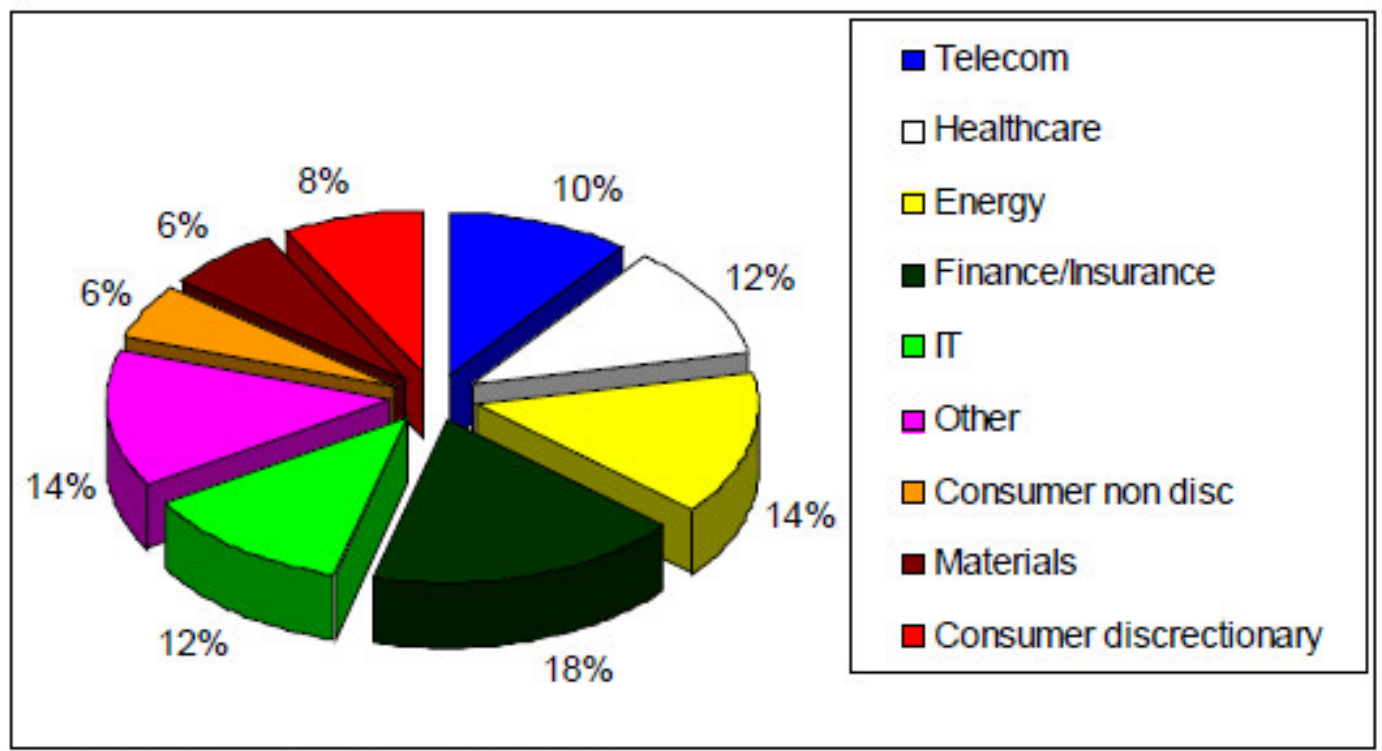

Graph A.8 - Sector Breakdown (May 2009)

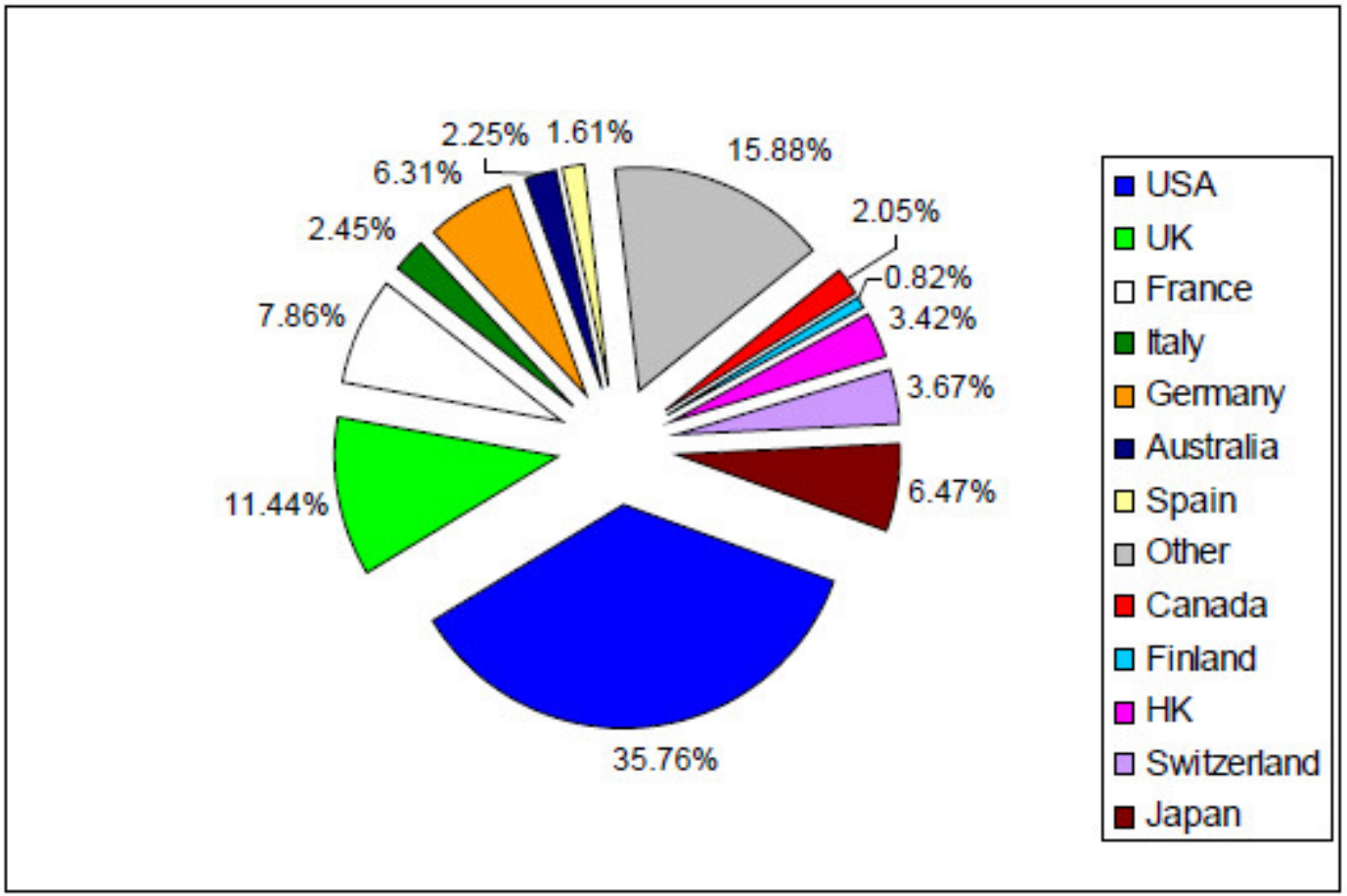

Graph A.9 - Country Breakdown (May 2009) 


\section{A.2.1 Remarks}

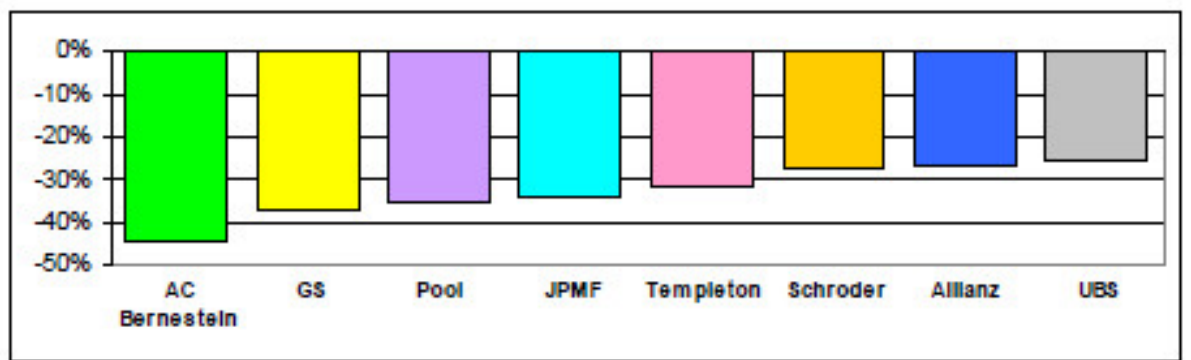

Graph A.10 - Absolute Returns

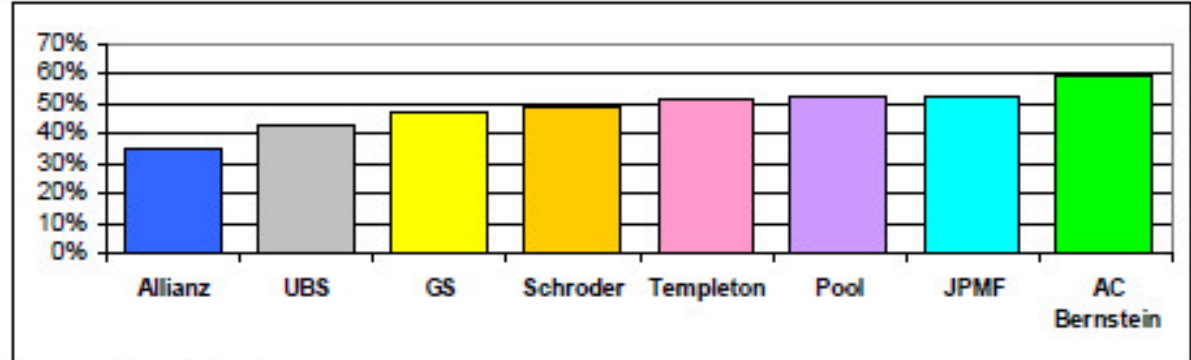

Graph A.11 - Volatility

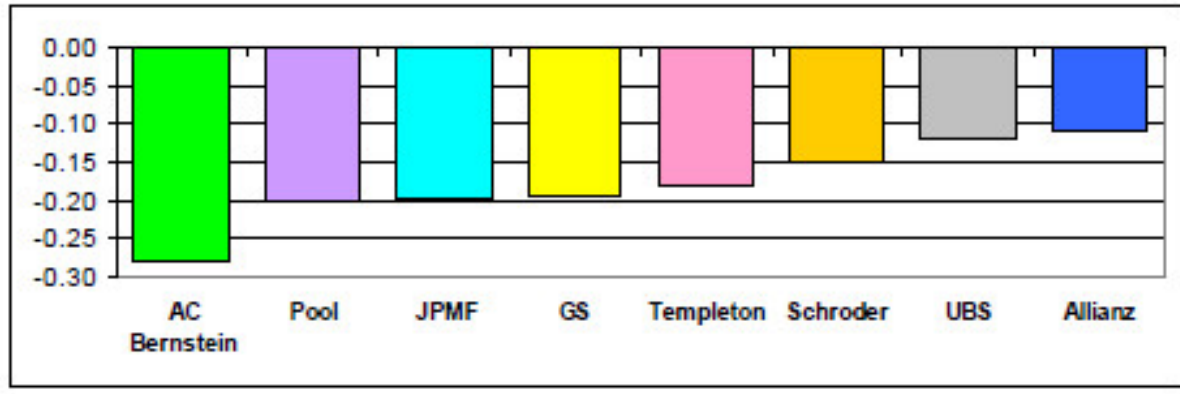

Graph A.12 - Sharpe Ratio Modified

The most evident characteristic of analysed Islamic equity funds is the performance. Although negative, both funds reported higher returns than all considered traditional funds: actually, only the Schroder fund reported a return comparable to Islamic funds. Particularly, the difference could be found in the better response of Islamic funds during the peak of the crisis: while the traditional funds followed the market (MSCI World) in the sub-60 area, Islamic funds barely broke this threshold.

This can be partially explained by the absence in Islamic portfolios of the seriously hit financial sector (that weights around $18 \%$ in traditional portfolios and it is compensated by an higher weight of technological sectors) and generally a lower Beta.

A similar discussion could be held regarding volatility; again Islamic funds 
resulted to be a safer investment with values well below the traditional products average.

Consequently, the sum of these two variables resulted in Islamic equity funds outperforming (relatively speaking) the market and other funds: in fact the Sharpe ratio (or better, the modified version adapted to negative returns) is sensibly higher than other funds considered.

Another interesting point is the diversification problem. The Islamic funds don't show particular sectors diversification limitations, although the average number of different companies present in their portfolios is lower than in a traditional fund. The major downside seems the countries concentration: both Islamic funds are strongly focused on a bunch of countries, particularly Anglo-Saxon ones (USA, UK, Canada and Australia make more than $70 \%$ of the portfolios, while in traditional ones the percentage is only around 50\%). This is mainly due to the different corporate establishment existent in different countries: Continental European countries as Germany or France are dominated by financial institutions and other industries usually not favoured by Islamic provisions (e.g. heavy industries) so they are more easily filtered by Islamic financial ratios provisions, while in Anglo-Saxon countries there are strong companies operating in favourable sectors (e.g. Energy, Telecom and Personal Goods). Using the Fama's diversification measure, it is possible to observe that the Allianz fund shows no particular problem (the value is nearly 0), while the UBS fund actually shows some problems (the value is around 0.03). It seems that the characteristic diversification problem of older funds has disappeared in newer ones.

Last but not least, it is important to analyse the differences in terms of expenses. The "historical" fund (UBS) shows some of the Islamic equity funds common problems: a higher front-load (95 bps) and higher management fees (50 bps). This problem does not affect the more recent Allianz fund, both the front-load and management fees are comparable to traditional funds. However, it is important to underline that the better performances, in the considered framework, more than compensate any major cost. 


\section{A.3 Global Equity ETFs}

\section{ISHARES MSCI WORLD ISLAMIC}

ISIN:

Launch Date:

Net Assets:

Front End Load:

Management Fee (p.a.):

Abs Return:

Max/Min:

Volatility:

Sharpe Ratio:

Sharpe Ratio (mod):

Beta:
IE00B27YCN58

07/12/2007

$11.9 \mathrm{mln}$ USD $(31 / 03 / 2009)$

$0.00 \%$

$0.60 \%$

$-31.36 \%$

$+0.39 \% /-47.92 \%$

$39.56 \%$

$-0.73$

$-0.16$

0.80

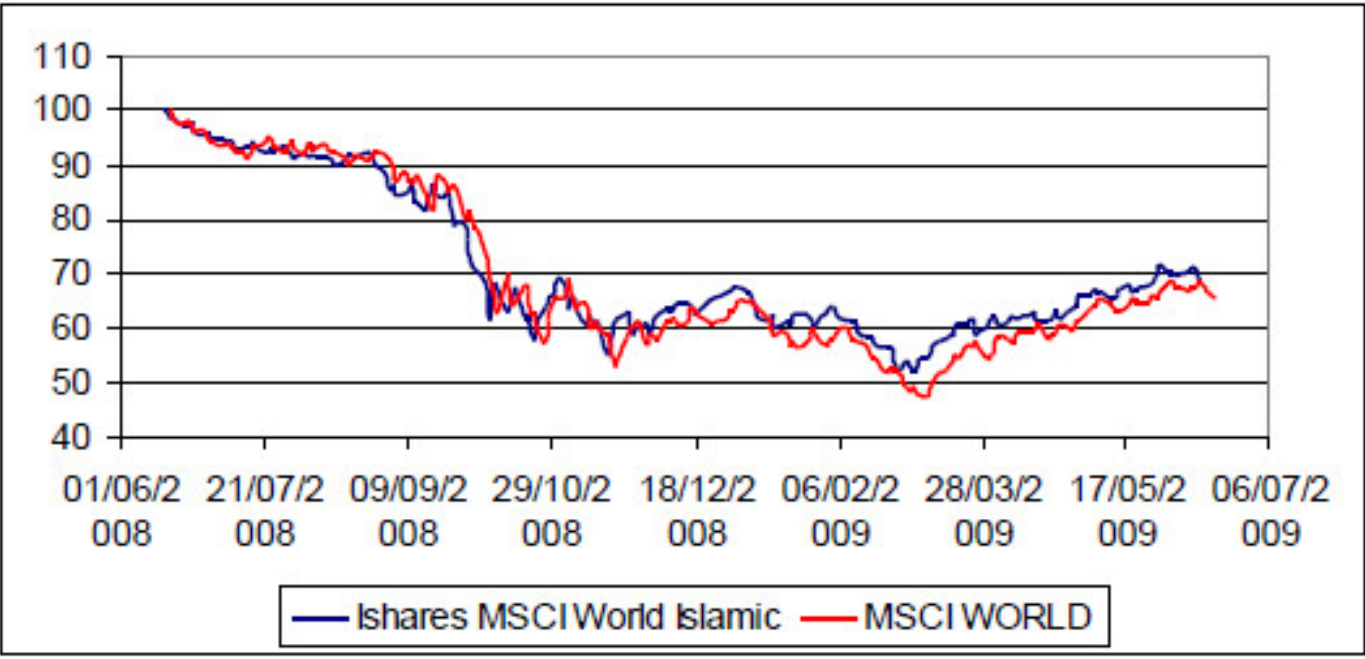

Graph A.13 - Value (100 = value on June 17th 2008) 


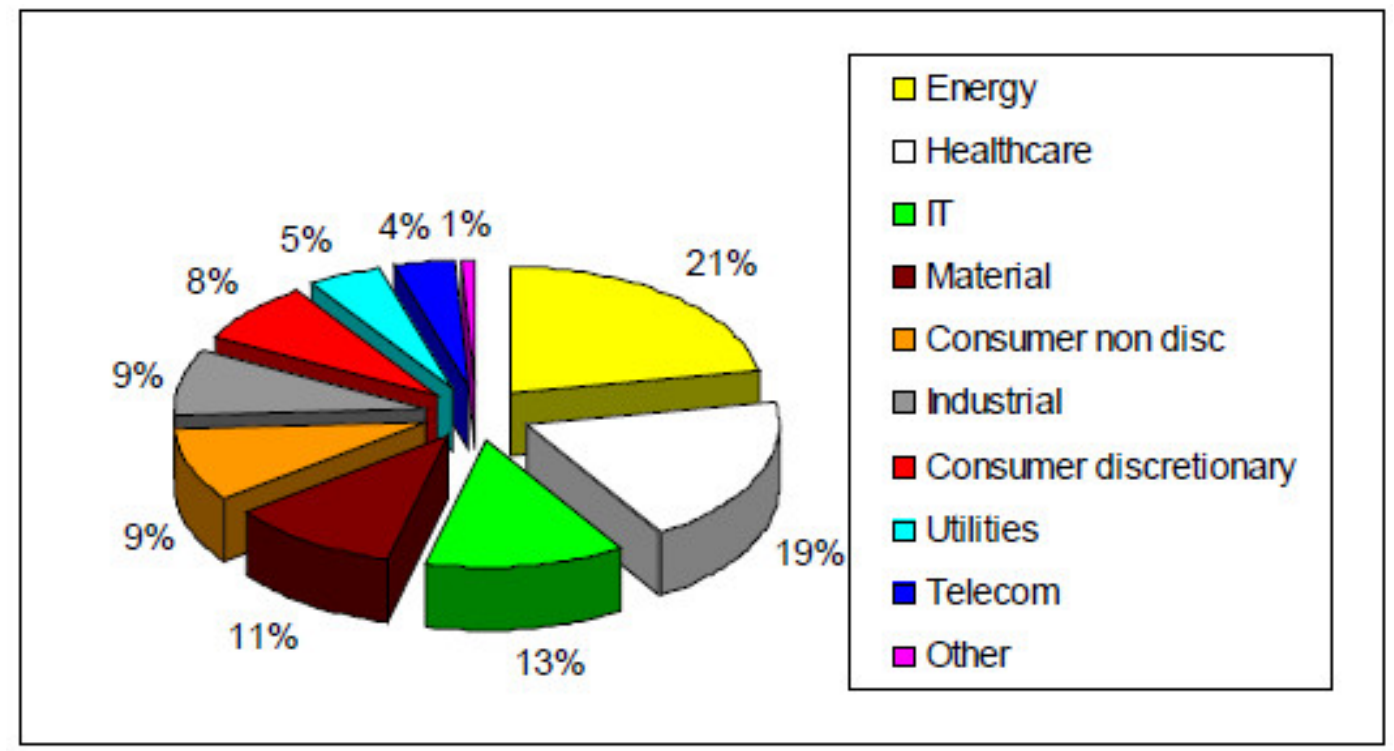

Graph A.14 - Sector Breakdown (May 2009)

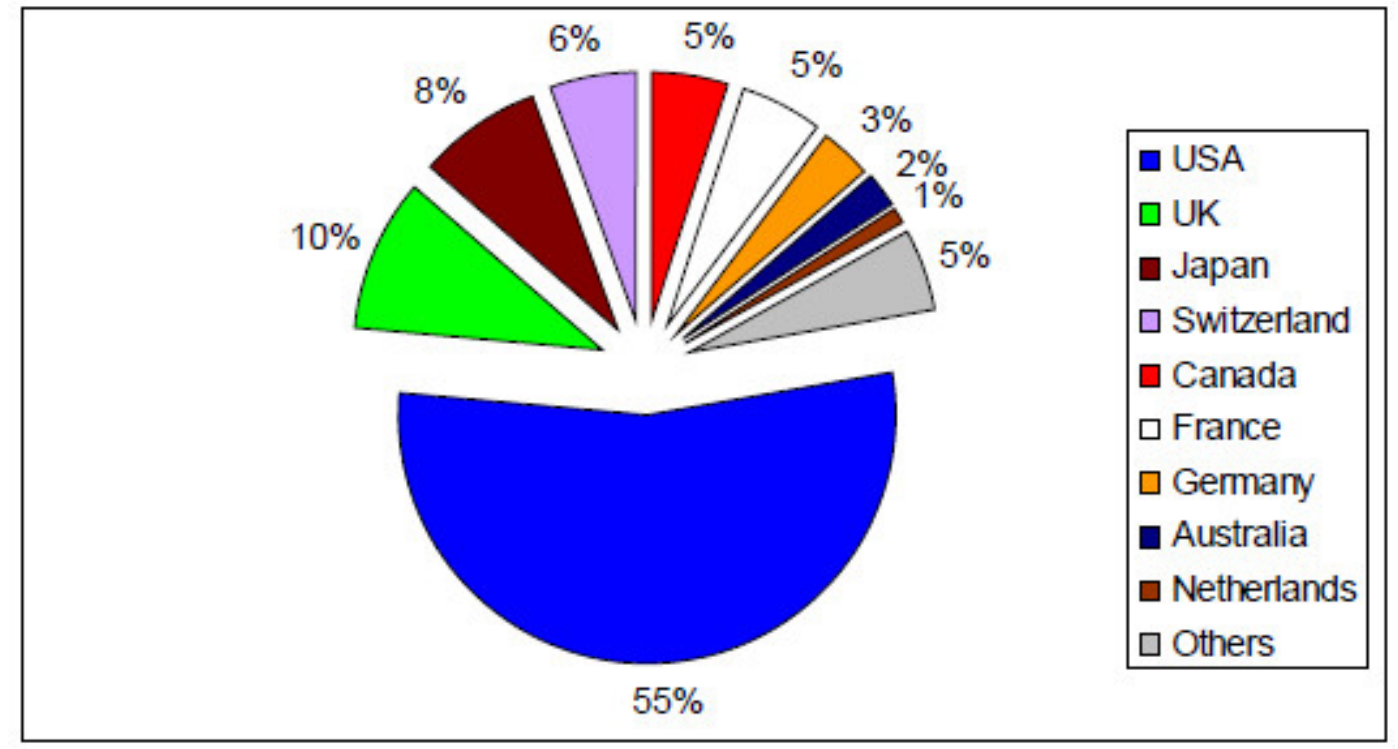

Graph A.15 - Country Breakdown (May 2009) 


\section{ISHARES MSCI WORLD}

ISIN:

Launch Date:

Net Assets:

Front End Load:

Management Fee (p.a.):

Abs Return:

Max/Min:

Volatility:

Sharpe Ratio:

Sharpe Ratio (mod):

Beta:
IE00B0M62Q58

$27 / 10 / 2005$

1.6 bln USD (31/03/2009)

$0.00 \%$

$0.50 \%$

$-33.04 \%$

$+0.33 \% /-52.19 \%$

$41.82 \%$

$-0.73$

$-0.18$

0.91

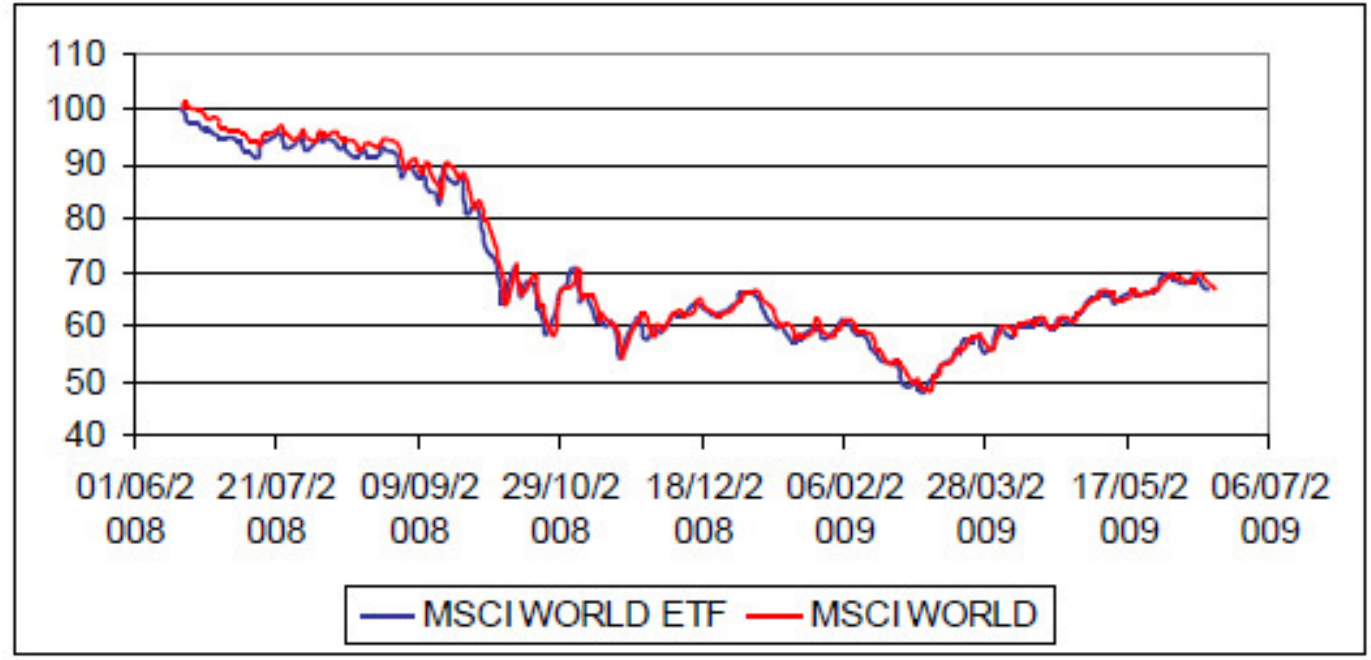

Graph A.16 - Value $(100=$ value on Jine 17th 2008) 


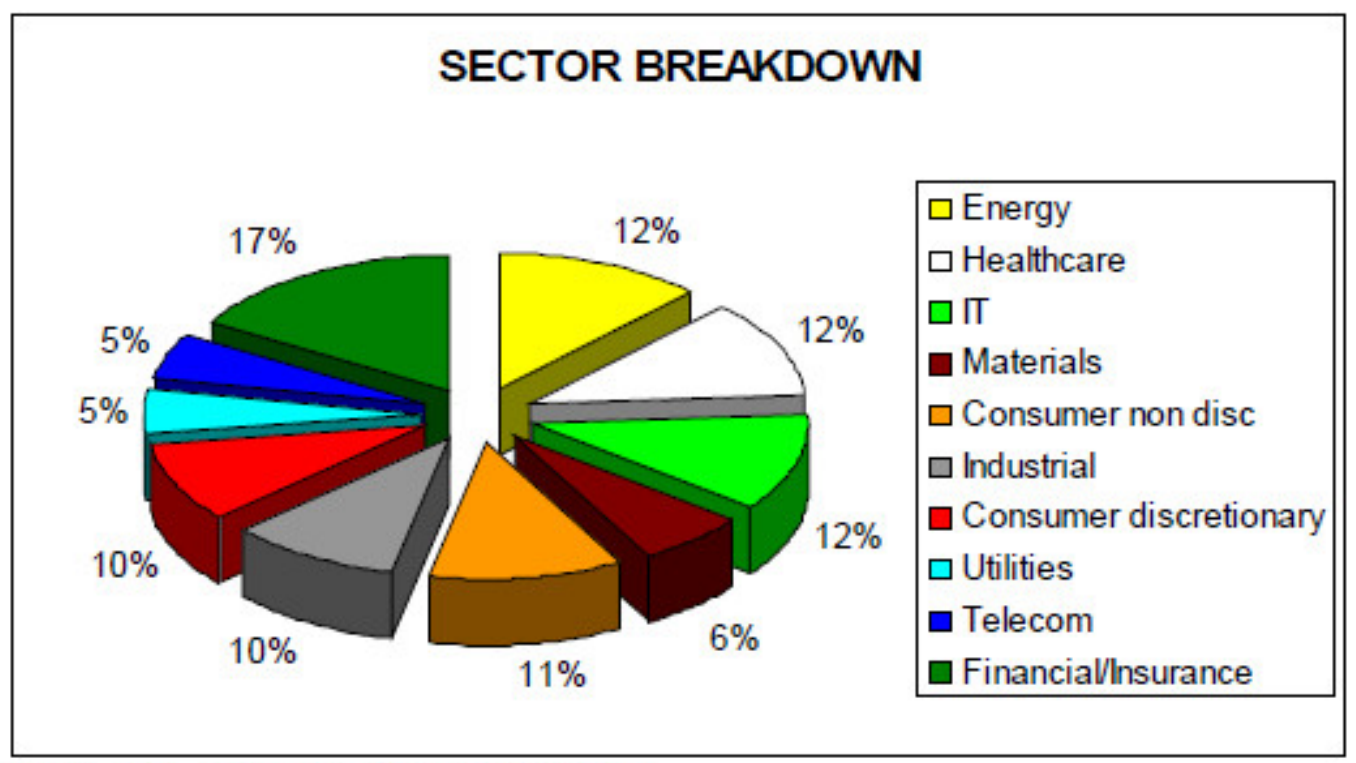

Graph A.17 - Sector Breakdown (May 2009)

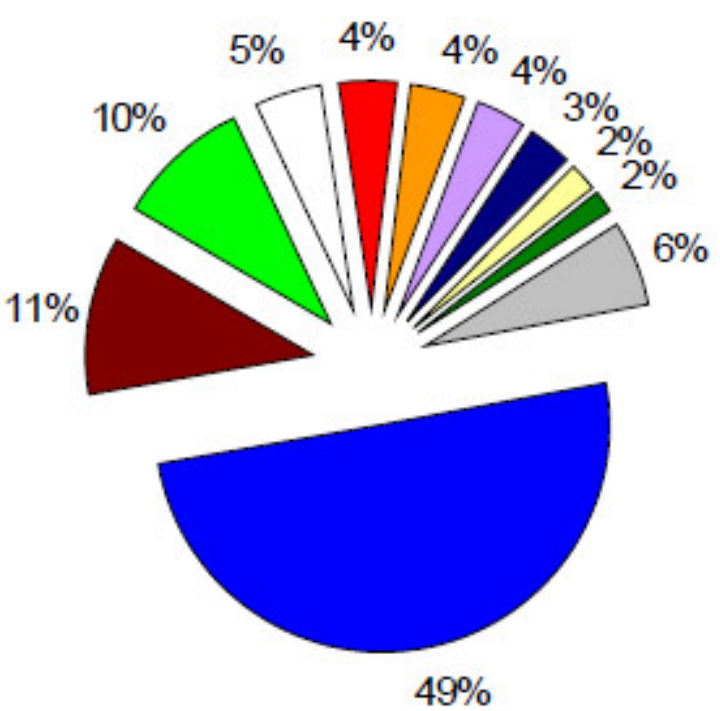

- USA

- Japan

$\square$ UK

$\square$ France

$\square$ Canada

$\square$ Germany

$\square$ Switzerland

- Australia

$\square$ Spain

$\square$ Italy

$\square$ Others

Graph A.18 - Country Breakdown (May 2009) 


\section{A.3.1 Remarks}

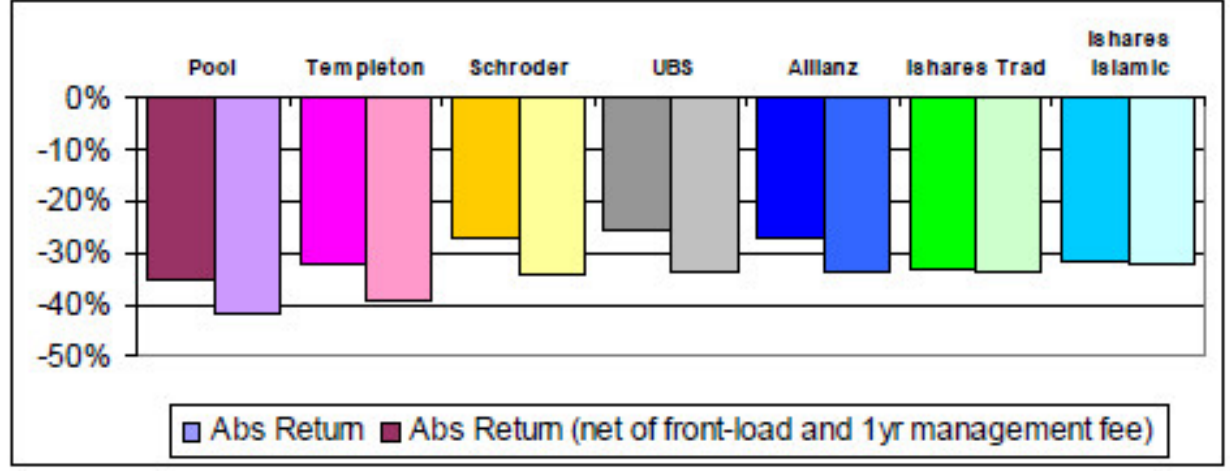

Graph A.19 - Absolute Returns

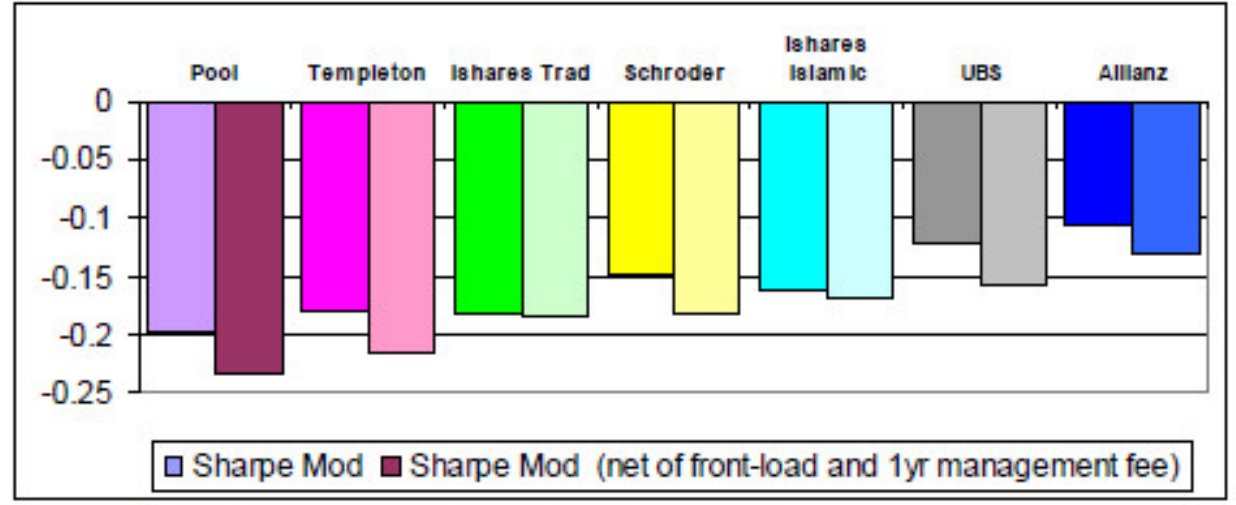

Graph A.20 - Sharpe Ratio Modified (without and with fees)

As already observed while speaking about mutual funds, also Islamic ETF registered in the considered period higher returns than its peers: either absolutely speaking, either relatively speaking. Islamic products, hence, offered a better performing and less risky investment solution in the world equity market.

An aspect that requires a particular attention is the comparison between mutual funds and ETFs, specially a comparison between Islamic funds and the Islamic ETF.

The most evident fact is that the Islamic ETF is way less performing and way more risky than the two Islamic mutual funds. The gap narrow down when considering expenses (are considered only the two types of fees usually critical for Islamic equity funds), in this case the ETFs (both the traditional one and the Islamic one) would have offered higher returns. It is important 
to underline that, evaluating relative returns, Islamic mutual funds still offer a better solution.

Due to the chronic lack of data (there is only a bunch of Islamic equity ETFs), it is difficult to reach a conclusion. However, it is possible to find the explanation of the discrepancies between Islamic products in the different structures: the mutual funds are characterized by a variable level of discretion, while ETFs are strongly linked to the underlying index. The limited flexibility clearly creates diversification problems.

In few words Islamic ETFs could be a cheaper alternative, but they cannot be considered a full alternative. While traditional ETFs offer performances similar to equal mutual funds at a discounted price, Islamic ETFs seem offering a products characterized by much lower expenses but without the traditional pros of Islamic equity products. While they are currently a valid alternative to old-fashioned products like the UBS one, they are more convenient than newer products only for short-term investments. 


\section{A.4 Sharpe Ratio in Funds Comparison}

One of the most critical point in using the Sharpe ratio is when dealing with negative ratios. In this case, with equal negative return, a higher volatility means an higher Sharpe ratio. There are actually three different way to interpret this result:

- Negative Sharpe ratio is nonsense, no one would accept a return lower than the risk free. So, a negative ratio is NA

- It is better to achieve the same negative return with a higher volatility because there were also higher profit potential.

- Modify the formula, replacing volatility with $1 /$ volatility

In the fund comparison section, we used the latter interpretation. In fact it is the only that respect the mean-variance theorem (that is the basis of Sharpe ratio).

In this appendix, we will make a similar comparison using the non-modified ratio 


\section{A.4.1 Remarks}

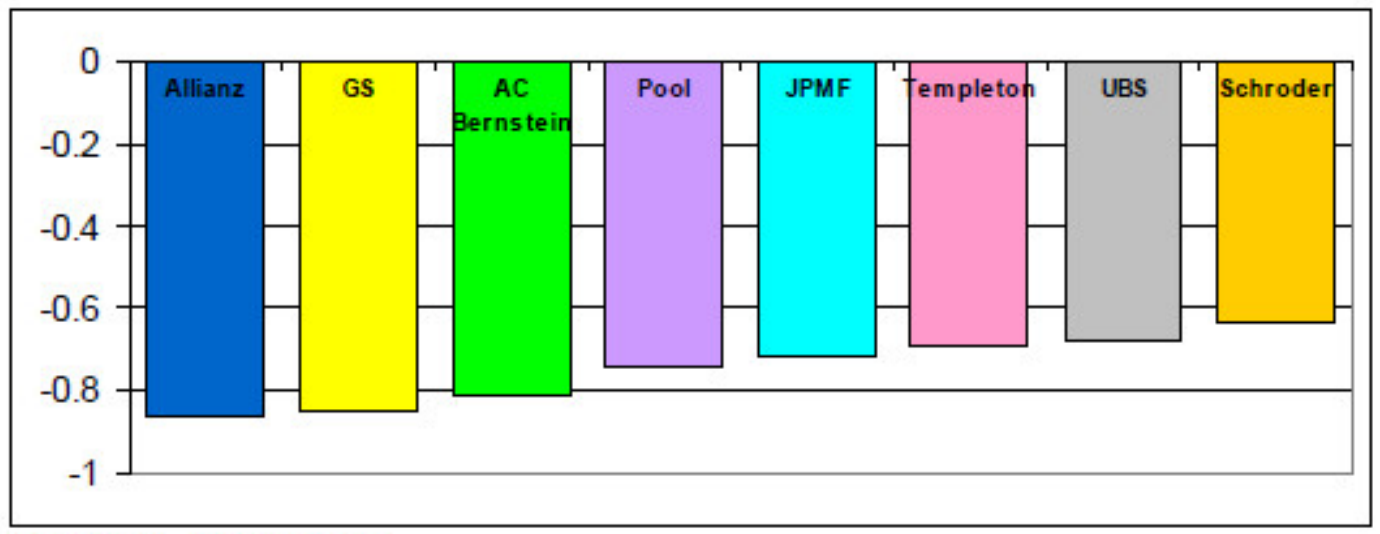

Graph A.21 - Sharpe Ratio

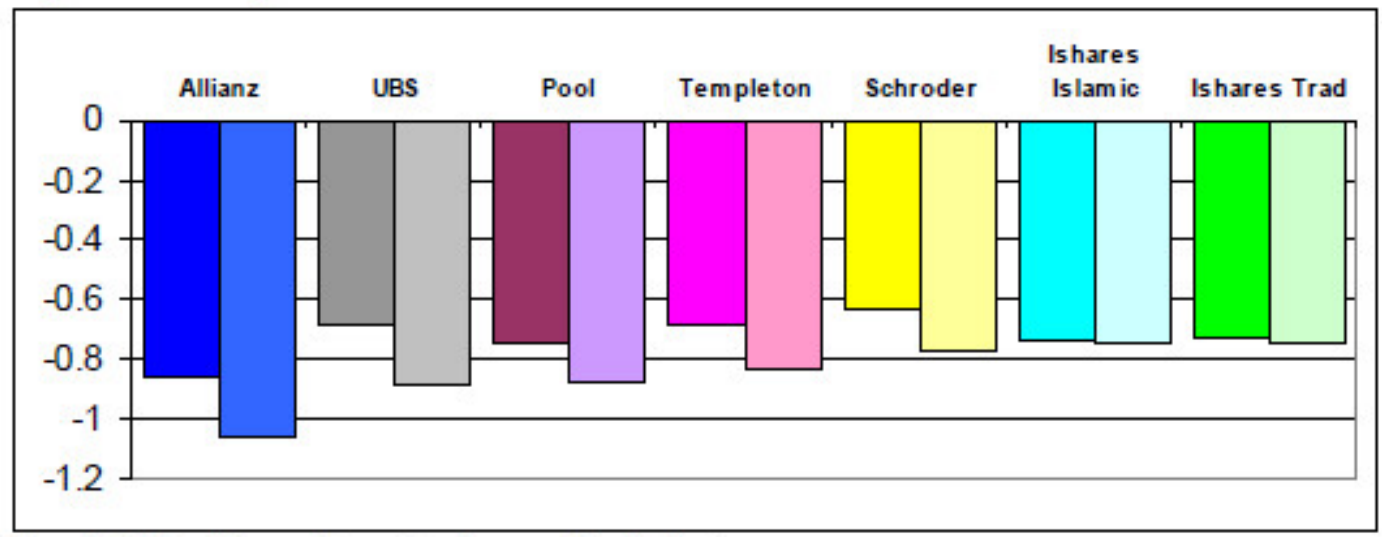

Graph A.22 - Sharpe Ratio (without and with fees)

It is evident that using this interpretation, the conclusions also are affected.

Without considering expenses, the UBS fund (although not the best option any more) still retain a top position. Instead, the Allianz fund switches from the 2nd to the last position: the return is excessively negative compared to the low risk involved.

Considering also expenses, the UBS fund report results nearly aligned with other traditional funds while, obviously, the Allianz fund falls in the last position. In this framework the two ETFs (Islamic and not) dominate with ratios higher than similar mutual funds.

This different approach reveal a different side of the Islamic equity fund industry: although generally much less risky, the absolute returns are not equally much higher. A reliable consideration should consider the type of investor: 
- a short-term investor without risk constraints would find in ETFs his ideal product

- a long-term investor without risk constraints should opt for a good mutual fund or an "old-style" (more market dependent) Islamic fund

- a risk adverse investor should opt for Islamic funds, better the newer ones (low Beta) 


\section{References}

[1] Abderrezak, F. The Performance of Islamic Equity Funds: A Comparison to Conventional, Islamic and Ethical Benchmarks. MA Thesis. University of Maastricht - Maastricht, NL. 2008.

[2] Ayub, M. Understanding Islamic Finance. John Wiley \& Sons - Hoboken, USA. 2007.

[3] Babikir Ahmed, O. Islamic Equity Funds. Paper. Islamic Development Bank - Jeddah, KSA. 2001.

[4] Bastaki, N. A. Assessing the Explanatory Behaviour Of Islamic Equity Screening Norms and Analyzing an Islamic Stock Selection Strategy. MSc Project. Imperial College - London, UK. 2008.

[5] Brunoni, G. Islamic Finance in Italy. Business Islamic - June 08, pp 44 - 46. 2008.

[6] Edouhabi, F. Strumenti di Finanza Islamica per le Banche Commerciali Occidentali. Master Thesis. University of Bologna - Bologna, IT. 2005.

[7] Forte, G. and Miglietta, F. Islamic Mutual Funds as Faith-Based Funds in a Socially Responsible Context. Working Paper. Bocconi University Milan, IT. 2007.

[8] Kraeussl, R. and Hayat, R. The Performance of Islamic Equity Funds. Working Paper. VU University Amsterdam - Amsterdam, NL. 2008.

[9] Lombardi, R. Finanza Islamica, Opportunità e Limiti. MSc Thesis. University of Rome "La Sapienza" - Rome, IT. 2009.

[10] Pfeiffer, D. and Stewart Staff, R. Islamic Banking and Finance. Spiramus Press - London, UK. 2008.

[11] Steiner, A. Investment Performance Analysis and Risk Management. Zurich, CH. 2006.

[12] Usmani, T. Principles of Shariah Govening Islamic Investment Funds. in Islamic Mutual Funds as Faith-Based Funds in a Socially Responsible Context. 2007.

[13] VV.AA. Islamic Investments. Norton Rose Group - London, UK 2008.

[14] VV.AA. The Islamic Funds $\&$ Investments Report. Ernst \& Young Luxembourg, LUX. 2008. 
[15] VV.AA. The Islamic Funds \& Investments Report. Ernst \& Young Luxembourg, LUX. 2009.

[16] Walder, U. and Erny, D. Islamic Funds. Working Paper. Hochschule Luzern - Luzern, CH. 2007.

[17] Wilson, R. Islamic Finance in Europe. RSCAS Policy Paper No. 2007/02. University of Durham - Durham, UK. 2007. 


\section{THANKS}

Foremost, I would like to thank Professor Stefano Gatti for supervising my work and for all the help he has provided.

I would also thank all the other people that made this paper possible.

Stefano Collina 